\title{
"Tutaj jest bardzo zimno...". Życie codzienne niemieckiej urzędniczki w Poznaniu opisane na widokówkach z lat 1941-1944
}

Streszczenie. W jednej z największych w Polsce kolekcji pocztówek, znajdującej się w ikonograficznych zbiorach Biblioteki Uniwersyteckiej w Poznaniu, znalazło się prawie sto kartek od jednego nadawcy, Wery V. - niemieckiej urzędniczki Stowarzyszenia Rolników Kraju Warty (Landesbauernschaft Wartheland), do tego samego odbiorcy - jej matki zamieszkałej w Hamburgu, wysyłanych z Poznania w latach 1941-1944. Początkowo Poznań był dość atrakcyjnym i spokojnym miejscem pracy w porównaniu z często bombardowanym Hamburgiem - pensja bez podatku, niektóre artykuły reglamentowane w Rzeszy tu bez kartek dla urzędników niemieckich, trzy naloty alianckie. W miarę upływu wojny pogarszały się warunki życia i pracy Wery.

Prawdopodobnie obawa przed cenzurą i autocenzurą sprawiły, że nie ujawniła swego stosunku do narodowego socjalizmu. Jej postawę wobec Polaków trudno uznać za wrogą. Czas wolny przeznaczała przede wszystkim na korespondencję, poszukiwanie artykułów trudnych do zdobycia w głębi Rzeszy, wysyłanie paczek ze zdobyczami lub praniem czy ubraniami do przerobienia. Rzadko bywała w kinie, kawiarni, teatrze i operze - jeśli tak, to często z powodu zimna. Dużo pisała o pogodzie, niewiele o swej pracy. Dopiero od sierpnia 1944 roku, kiedy zapanował chaos, informowała o zmianach w jej biurze i o zamykaniu oddziałów zamiejscowych.

Pisane przez nią widokówki były uzupełnieniem listów do matki. Lektura całej korespondencji pozwoliłaby na pełniejsze odtworzenie życia codziennego Wery V. w Poznaniu.

SŁowa KLuczowe: życie codzienne, druga wojna światowa, Poznań, widokówki

Od początku lat dziewięćdziesiątych ubiegłego wieku kartki pocztowe stały się obiektem intensywniejszych studiów i badań naukowych w Polsce. Uwaga badaczy skoncentrowana była głównie na przełomie XIX i XX 
wieku oraz okresie międzywojennym ${ }^{1}$. Znacznie rzadziej zakres ich zainteresowań obejmował okres II wojny światowej i okupacji niemieckiej². Przedmiotem badań nad życiem codziennym ${ }^{3}$ był przede wszystkim awers kart, a nie treść zawartej w nich korespondencji ${ }^{4}$.

Jedną z największych kolekcji pocztówek w Polsce ma Biblioteka Uniwersytecka w Poznaniu za sprawą kierownika Pracowni Ikonograficznej-Jakuba Skuteckiego - autora i współautora wielu albumów oraz opracowań historii poznańskich widokówek ${ }^{5}$ W zbiorach ikonograficznych Biblioteki Uniwersyteckiej znalazło się około stu pocztówek ${ }^{6}$ od jednego nadawcy - niemieckiej urzędniczki Stowarzyszenia Rolników Kraju Warty (Landesbauernschaft Wartheland ${ }^{7}$ ) - Wery V. z lat 1941-1944. Awers większości kart przedstawia widoki z Poznania (jedna z nich portret namiestnika Kraju Warty - Arthura Greisera, a sześć innych widoki z podpoznańskiej miejscowości Mosina). Wśród nich tylko dwie (poza wspomnianym portretem Greisera) mają charakter propagandowy: jedna przedstawiająca plac Wolności 1 września 1939 roku i w 1941 roku, druga - wejście wojsk niemieckich do Poznania.

${ }^{1}$ Por. m.in. Aksjosemiotyka karty pocztowej, red. P. Banaś, Wrocław 1992; Aksjosemiotyka karty pocztowej II, red. P. Banaś, Wrocław 2004; P. Banaś, Orbis Pictus: świat dawnej karty pocztowej, Wrocław 2005; M. Baranowska, Posłaniec uczuć: prywatna historia pocztówki, Warszawa 2003; J. Kotłowski, Dawne pocztówki: historia - ikonografia - kolekcjonerstwo, Warszawa 1998; Miasto na pocztówce. Poznań na tle porównawczym, red. R. Jaworski, W. Molik, Poznań 1999; M. Warkoczewska, Poznań wczoraj, Gliwice 1998; J. Zieliński, Historia karty pocztowej, Krosno 1999.

2 J. Kotłowski, Toruń w dawnej pocztówce. Katalog pocztówki toruńskiej z lat 1890-1945 z Biblioteki Uniwersyteckiej w Toruniu, Toruń 1991; J. Zieliński, Pozdrowienie z Krakowa, Krosno 2005.

${ }^{3}$ Przez to pojęcie rozumiem „całą kulturę materialna, życie rodzinne, obszary pracy i wypoczynku, świat pojęć indywidualnych i grupowych”. M. Bogucka, Życie codzienne - spory wokót profilu badań i definicji, „Kwartalnik Historii Kultury Materialnej” 1996, nr 3, s. 252.

${ }^{4} \mathrm{~J}$. Hoff, Pocztówka jako źródło historyczne do dziejów kultury życia codziennego i obyczajowości w XIX wieku, „Prace Humanistyczne” 1986, nr 26, s. 161-184; Postkarten erzählen Geschichte: Die Stadt Posen 1896-1918. Pocztówki opowiadaja historię: Miasto Poznań 1896-1918, red. S. Kemlein, Lüneburg 1997.

${ }^{5}$ J. Skutecki, Poznań na dawnych widokówkach, cz. 1: Widokówki z lat 1896-1905, Poznań 1995; cz. 2.1-2.5: Widokówki z lat 1905-1918, Poznań 1995-1997; idem, Poznań na widokówkach z lat 1893-1918: ze zbiorów ikonograficznych Biblioteki Uniwersyteckiej w Poznaniu, Poznań 2000; Ulicami Poznania, red. J. Skutecki, M. Jańczak, T. Piskorski, Poznań 2003; J. Skutecki, Warte Poznania, Poznań 2007.

${ }^{6}$ Zostały zakupione od osoby prywatnej (najprawdopodobniej przywiezione z Niemiec).

${ }^{7}$ Ta okręgowa organizacja rolników z siedzibą w Poznaniu była oddziałem Administracji Żywnościowej Rzeszy (Reichnährstand). Została utworzona w Kraju Warty 23 stycznia 1940 roku. Zajmowała się rolnictwem, a także handlem artykułami rolnymi i leśnymi. C. Łuczak, Dzień po dniu w okupowanym Poznaniu: 10 września 1939-23 lutego 1945, Poznań 1989, s. 93. 


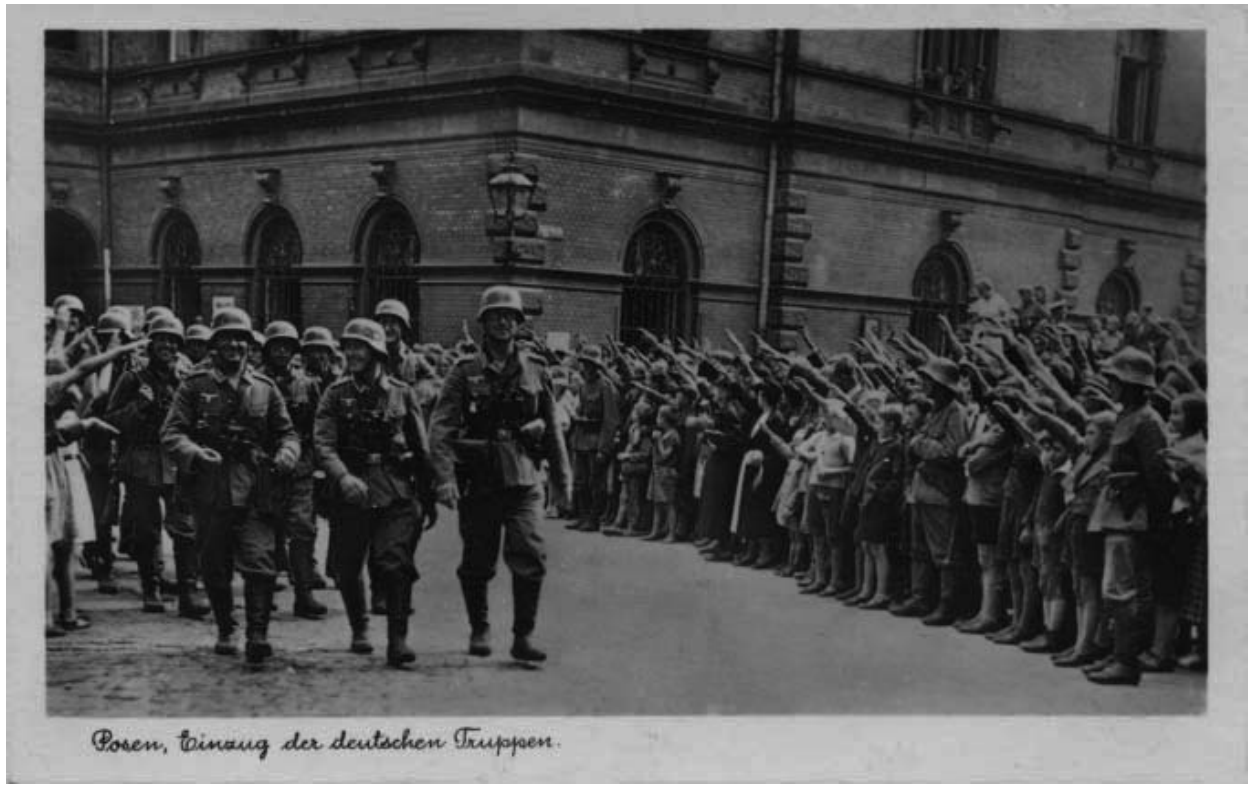

Wejście wojsk niemieckich do Poznania (kartka z 15 lipca 1942 roku)

Autorka korespondencji bardzo dbała o dobór widokówek. Nie powtórzyła się żadna, choć zdarzały się te same widoki, m.in.: Uniwersytetu, Zamku, gmachu dzisiejszego Teatru Wielkiego, dzisiejszego placu Wolności i kilku ówczesnych restauracji. W każdym wypadku były to inne ujęcia, różne pory dnia lub roku. Być może Wera kolekcjonowała pocztówki, a może były one przeznaczone dla pasjonata zbierania widokówek z rodziny. Przypuszczalnie kupowała jednorazowo większą partię widokówek, na co wskazywałoby na przykład wysyłanie ich w 1944 roku ze stemplem polskiego zakładu fotograficznego (Foto Wimar), a wszystkie one zostały przejęte przez niemieckich właścicieli najpóźniej w 1941 roku $^{8}$. Większość kartek nie została oznaczona stemplem wydawcy lub zakładu fotograficznego. Spośród ostemplowanych najwięcej wykonano w Foto Weber i Verlag Heinrich Hoffmann Posen (rzadziej z nadrukiem München, gdzie mieściła się główna siedziba wydawnictwa).

${ }^{8}$ Zakład Foto Wimar należał do znanego fotografa Witolda Czarneckiego. Zmienił nazwę na Foto Weber po przekazaniu go niemieckiemu właścicielowi Nicolaiowi Weberowi, który przejął również wydawnictwo Fotoverlag Hanns Kanngiesser z Łodzi. M.Y. Arani, Fotografische Selbst- und Fremdbilder von Deutschen und Polen im Reichsgau Wartheland 1939-45. Unter besonderer Berücksichtigung der Region Wielkopolska, Hamburg 2008, s. 832-833, 912. 
Wszystkie kartki zaadresowane zostały do matki autorki, Elise V., zamieszkałej w Hamburgu. Stamtąd Wera przybyła do Poznania w lutym 1941 roku - najprawdopodobniej w wyniku przeniesienia służbowego.

Pierwsza widokówka z kolekcji została wysłana 5 lutego 1941 roku:

Przyjechałam tu drogą okrężną. Przenocowałam w poczekalni Charlottenburg ${ }^{9}$. Bilety wyślę jutro listem poleconym [...]. Tymczasowo musimy przeprowadzać się co dwa dni. Zarobki dobre, bez podatku ${ }^{10}$. Zaczynamy siódmego ${ }^{11}$.

\section{Dziękując matce za paczkę, w kartce z 5 marca 1941 roku Wera napisała ${ }^{12}$ :}

Jestem rozczarowana, po cichu miałam nadzieję, że będzie w niej chociaż mufka. Tutaj jest straszliwie zimno i lodowaty wiatr. Wszyscy narzekają a ulice są puste. Siedzę w kawiarni i boję się pójść do domu. Wciąż nie ma ogrzewania [...]. Dziś mam ostatni wolny dzień. Najprawdopodobniej spotkam się wieczorem z Kurtem ${ }^{13}[\ldots]$ udało mi się załatwić bilety do kina. Grają „Zielone domino"14. Widziałam już ten film 5 lat temu w Hamburgu. Jest świetny i prawie wszędzie bilety były już sprzedane... ${ }^{15}$.

Już w tych pierwszych pocztówkach córka niepokoiła się brakiem wiadomości od matki:

Wciąż nadaremnie czekam na pocztę od Ciebie. Czy coś się stało? Dlaczego nie piszesz? Co się dzieje w Borgfelde ${ }^{16}$ ? Tutaj krążą szalone pogłoski. Poproś cio-

${ }^{9}$ Jedna ze stacji kolejowych Berlina.

${ }^{10}$ Od grudniu 1940 roku obowiązywało zarządzenie o "pomocy podatkowej dla Wschodu" (Oststeuerhilfe). C. Łuczak, Pod niemieckim jarzmem (Kraj Warty 1939-1945), Poznań 1996, s. 132-133.

${ }^{11}$ Kartka z widokiem gmachu Teatru Wielkiego (Stadttheater) - sygn. IV-Vas-1941-02-05. Tłumaczenie tekstu widokówek - D.M.

${ }^{12}$ Z treści późniejszych widokówek wynika, że autorka wysyłała do matki także paczki z listami. Prawdopodobnie wcześniej w liście poprosiła o przysłanie paczki z ciepłymi rzeczami.

${ }^{13}$ Przypuszczalnie narzeczony Wery.

${ }^{14}$ Film Der grüne Domino to dramat kryminalno-społeczny w reżyserii Herberta Selpina (według sztuki teatralnej Ericha Ebermeyera Der Fall Claasen) dozwolony od 16 lat. Premiera odbyła się w Niemczech w 1935 roku. Lexikon des internationalen Films: das komplette Angebot in Kino und Fernsehen seit 1945: 21000 Kurzkritiken und Filmographien, t. 3: G-H, red. K. Brüne, Reinbek 1991, s. 1445.

${ }^{15}$ Pocztówka z widokiem Wilhelmplatz (pl. Wolności) z restauracją "Arkadia”, sygn. IV-Vas-1941-03-05.

${ }^{16}$ Borgfelde - dzielnica Hamburga. 
cię E., żeby napisała. Ona ma przecież więcej czasu [...]. Czy przyszły rzeczy? Mam bardzo mało czasu. Zawsze popołudniami chodzimy do domu wzdłuż Zamku $^{17}$. Jutro pojedziemy za 10 fenigów ${ }^{18}$.

Tydzień później martwiła się:

Napisz wreszcie. Żyję w ciągłym niepokoju, że znowu coś się stało. Dostałam 6 dni specjalnego urlopu ${ }^{19}$ na Wielkanoc. Chciałam pojechać na pracowniczy bilet powrotny za pół ceny [...]. Za pół ceny mogą jechać tylko żonaci. Co za podłość. To byłoby zbyt drogo na tak krótki czas. Jeszcze na dodatek pociągi ciągle wypadają i w podróży jest się całą wieczność. Co sądzisz o tym? Chyba zostanę tutaj. Tu jest ciągły ruch. Bardzo mi się tutaj podoba. Tylko panią W. posłałabym do diabła ${ }^{20}$.

W kolejnej kartce z 22 marca 1941 roku Wera napisała, że udało się jej kupić świeżą kiełbasę, którą wysłała matce w paczce. Można się domyśleć, że była to rzadka zdobycz nawet dla pracownicy Stowarzyszenia Rolników Kraju Warty, choć jeszcze niereglamentowana dla niemieckich urzędników ${ }^{21}$ :

Zjadłam właśnie 9 serdelków, jestem taka najedzona.

Do paczki włożyła także sukienkę do wyprania z zastrzeżeniem:

Nie mogę przysłać proszku do prania. Noszę teraz sukienkę z guzikami na ramieniu. Wygląda marnie, bo z przodu wypaliłam papierosem wielką dziurę. W szufladzie mojej szafy leży obcięty pas z dołu tej sukienki ${ }^{22}$.

${ }^{17}$ Siedziba Stowarzyszenia Rolników Kraju Warty mieściła się na Hohenzollernstraße 33 (ul. Mickiewicza). W tym czasie autorka często się przeprowadzała. Jako adres nadawcy podawała siedzibę swojej instytucji. Trudno więc ustalić, gdzie mieszkała na początku pobytu w Poznaniu.

${ }^{18} \mathrm{~W}$ tym czasie 10 fenigów kosztowały bilety tramwajowe za przejazd 4 przystanków. P. Dutkiewicz, Tramwaje w Poznaniu, Poznań 2005, s. 247. Pocztówka z widokiem Zamku i Coll. Minus, sygn. IV-Vas-1941-03-14 (Foto Weber).

${ }^{19}$ Takie okolicznościowe urlopy (poza urlopem wypoczynkowym) przysługiwały urzędnikom niemieckim, którzy mieli rodziny w głębi Rzeszy, z okazji świąt do marca 1942 roku. W. Porzycki, Posłuszni aż do śmierci: niemieccy urzędnicy w Kraju Warty 1939-1945, Poznań 1997, s. 138.

${ }^{20}$ Kartka z frontem Ratusza, sygn. IV-Vas-1941-03-21.

${ }^{21}$ Niemieccy urzędnicy w Kraju Warty mogli w tym czasie kupować na wolnym rynku wiele produktów spożywczych dostępnych w głębi Rzeszy tylko na kartki. W. Porzycki, op.cit., s. 127.

${ }^{22}$ Kartka z widokiem Ritterstraße (ul. Ratajczaka), sygn. IV-Vas-1941-03-22/a (Foto Wimar). 
Tego samego dnia pytała:

Czy potrzebujesz jeszcze cukier? To się zapewne wkrótce skończy... Nie mam jeszcze pokoju na stałe. Siedzę wciąż w płaszczu... Ale poza tym bardzo mi się tu podoba ${ }^{23}$.

W tych pierwszych doniesieniach autorki z Poznania brak jakichkolwiek odniesień do wydarzeń w mieście. Wera V. przechodziła codziennie przez centrum Poznania, a nie pisała nawet o neutralnych wydarzeniach, które mogła widzieć lub o których mogła słyszeć od innych współpracowników: 21 marca 1941 roku obchodzono na przykład w Poznaniu Dzień Pamięci Bohaterów i z tej okazji odbyła się defilada wojskowa. Córka pisała do matki tego i następnego dnia, nie wspominając tych zdarzeń ${ }^{24}$. Niezależnie od obawy przed cenzurą korespondencji musiała działać w jej wypadku także autocenzura spowodowana łatwym dostępem do treści każdej osoby, przez której ręce przechodziła kartka.

Treść korespondencji z pierwszych miesięcy nie wskazywała ani na pobyt autorki w Poznaniu, ani na czas trwania wojny. Gdyby nie widoki z Poznania na awersie kartek, stemple pocztowe i dodanie przez autorkę przed datą nazwy miasta Posen, widokówka mogła pochodzić z dowolnego miejsca. Sprawy życia codziennego były głównym tematem:

Znowu pada śnieg... Wczoraj wysłałam Ci paczuszkę z moją czerwonobrązową sukienką. Ona musi być natychmiast wyprana, bo ją przepociłam. Bardzo potrzebuję jeszcze ubrań, ponieważ tu nie można nosić kitli, a ciągle trzeba wyglądać schludnie. Niestety gotowe rzeczy nie pasują na mnie. Czy już postarałaś się o materiał na płaszcz? ${ }^{25}$

Po blisko dwumiesięcznej tułaczce po różnych pokojach Wera napisała do matki:

Nareszcie mogę rozpakować walizki. Właśnie dostałam pokój na stałe. W. ma także pokój ${ }^{26}$.

${ }^{23}$ Pocztówka z widokiem Uniwersytetu, sygn. IV-Vas-1941-03-22/c (Foto Weber).

${ }^{24}$ C. Łuczak, Dzień po dniu w okupowanym Poznaniu..., s. 215.

${ }^{25}$ Pocztówka z widokiem Wilhelmplatz z góry, sygn. IV-Vas-1941-03-25.

${ }^{26}$ Kartka z widokiem Ratusza, podpisana: przebudowany 1550-1555, sygn. IV-Vas-1941-03-29 (Verlag Heinrich Hoffmann, Posen). 


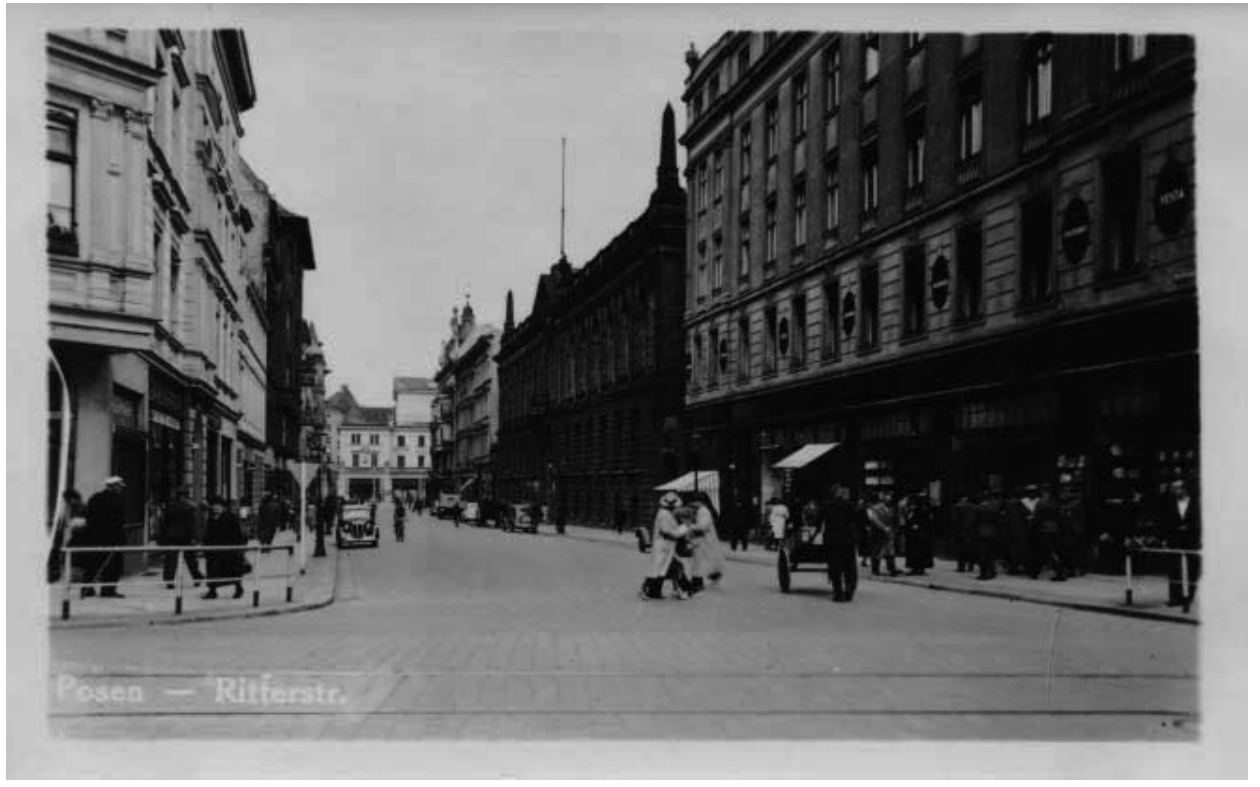

Ulica Ratajczaka (kartka z 22 marca 1941 roku)

Matka otrzymywała od Wery nie tylko listy, widokówki i paczki, ale także pieniądze:

Właśnie wysłałam paczuszkę i pieniądze. Musiałam ją przepakować, bo ważyła za dużo. Paczki dochodzą zbyt długo. Napisz natychmiast po otrzymaniu!27.

Po tygodniu braku korespondencji od matki niepokoiła się:

Co się właściwie dzieje? Czy doszły pieniądze? A te dwie paczuszki, których nadejścia jeszcze nie potwierdziłaś? W jednej jest moja czerwonobrązowa sukienka. Daj cioci E. znaczki i papier, żeby ona pisała, jeśli Ty nie masz czasu. Ile metrów materiału potrzebuję na bluzkę rubaszkę? Szybko muszę mieć coś nowego. Moje stare ciuchy już mi nie wystarczają, wszystkie są tak zniszczone. Tutaj stale trzeba być dobrze ubranym, bo obiad je się w restauracji i wieczorem także ${ }^{28}$. Nie można się przebrać dopiero na wieczór tak jak w Hamburgu. Musiałabym mieć z tuzin wąskich sukien. Można by je zmieniać przez kołnierzyk, pasek. Można się wściec, że na mnie nie pasują gotowe ubrania. A więc napisz w końcu! ${ }^{29}$

${ }^{27}$ Pocztówka z widokiem Bahnhofstr. (ul. Dworcowa), sygn. IV-Vas-1941-04-01.

${ }^{28} \mathrm{~W}$ tym czasie Niemcy nie musieli jeszcze oddawać $\mathrm{w}$ restauracjach kartek na mięso. C. Łuczak, Dzień po dniu w okupowanym Poznaniu..., s. 226.

${ }^{29}$ Widokówka z Berlinerstr. (ul. 27 grudnia), sygn. IV-Vas-1941-04-07. 
W widokówce wysłanej w kopercie autorka pochwaliła polskiego szewca:

Moje stare, czarne, zamszowe buty oddałam jeszcze raz do naprawy. Polski szewc zrobił je doskonale. Nasz hamburski szewc już by ich nie naprawił. Cukier jeszcze Ci przyślę ${ }^{30}$.

Tuż przed Wielkanocą Wera pisała, że musi pracować w Wielką Sobotę:

To nie jest takie złe, nic się nie robi, ale nie można się wyspać. Podczas przerwy obiadowej odebrałam mięso itd., a teraz czekam tylko aż wybije 5.30. Pani W. znowu wyszła dziś rano. Wczoraj zdrowo popiła i musi teraz spać. Każdy robi to, na co ma ochotę $e^{31}$.

W korespondencji autorka często zaznaczała, że nadała do matki paczki ze swoimi rzeczami do wyprania ${ }^{32}$.

Wysyłając kartkę z widokiem ul. Głogowskiej na wysokości Targów, zwróciła uwagę matki:

W białym domu, na prawo od schodów często jemy w czasie przerwy obiadowej. Naprzeciwko znajduje się Dworzec Zachodni, a za nim Dworzec Główny.

Zaraz po tym opisie mimochodem wspomniała:

Wczoraj w dniu urodzin Adolfa Hitlera aż do popołudnia była ładna pogoda. Wieczorem lało. W ciemnościach złamałam sobie obcas w moich dobrych, czarnych butach zamszowych... W środę o 3 muszę iść do dentysty. Poza tym dobrze mi się powodzi. Już teraz cieszę się na bluzkę. Czy na Zielone Świątki będą specjalne urlopy, jeszcze nie wiem. Trzy paczki są już w drodze. Napisz natychmiast, kiedy nadejdzie chociaż jedna ${ }^{33}$.

Trudno ocenić na podstawie tej i późniejszej korespondencji stosunek Wery V. do narodowego socjalizmu i Hitlera. Ta zdawkowa uwaga na te-

${ }^{30}$ Kartka z widokiem Wilhelmstr. (Al. Marcinkowskiego), sygn. IV-Vas-1941-04-08.

${ }^{31}$ Pocztówka z widokiem Kaiser Friedrich Museum (Muzeum Narodowe), sygn. IV-Vas-1941-04-11 (Foto Weber).

${ }^{32}$ Widok Uniwersytetu od strony Auli, sygn. IV-Vas-1941-04-16.

${ }^{33}$ Ul. Głogowska na wysokości Targów, sygn. IV-Vas-1941-04-21. 


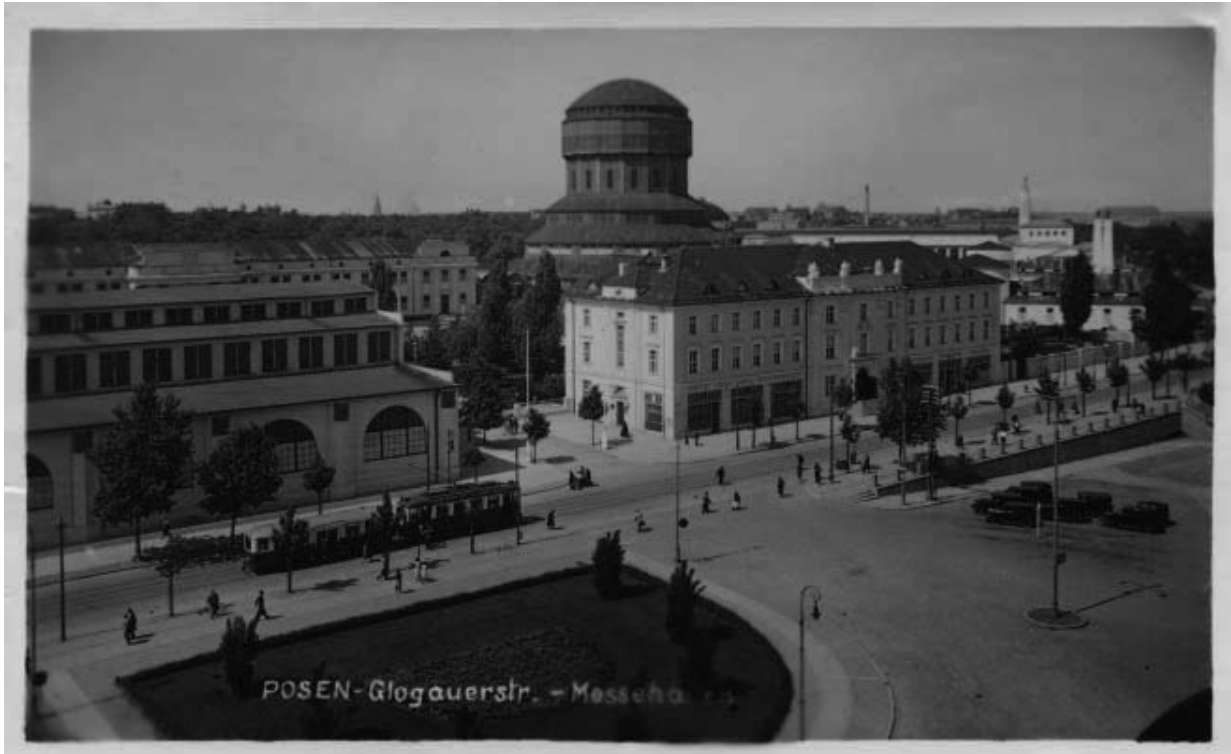

Ulica Głogowska na wysokości Targów (kartka z 21 kwietnia 1941 roku)

mat urodzin Führera w nawiązaniu do pogody tego dnia może świadczyć o tym, że nie bardzo wiedziała, jak zareagować na to święto, a uznała, że należy je odnotować.

Pod koniec kwietnia 1941 roku autorka wysłała znaną z okresu wojny kartkę propagandową z widokiem placu Wolności. Lewa strona przedstawiała plac poorany rowami przeciwlotniczymi z podpisem „Wilhelmplatz 1.IX.39”, a prawa - plac z klombami kwiatów i flagami nazistowskimi z napisem „jetzt” (teraz). Treść korespondencji nie nawiązywała do awersu widokówki. Wera ucieszyła się z paczki od matki, zapowiedziała też kolejną - z praniem. Zdziwiła się otrzymaną w paczce latarka, której nie potrzebowała i do której nie można było dostać baterii ${ }^{34}$.

Dopiero po trzech miesiącach jej pobytu w Poznaniu rzeczywistość wojenna pojawiła się na kartce pisanej nocą z 8 na 9 maja 1941 roku, wysłanej w kopercie:

Dzisiaj nocą o 2.30 było pierwsze, tajemnicze, wielkie bombardowanie, 2 minuty od mojego mieszkania. Chyba wyskoczyłam z łóżka. Wygląda strasznie. Nie wiem jeszcze nic bliższego z czyjej strony. Jeszcze Ci napiszę.

${ }^{34}$ Karta pocztowa sygn. IV-Vas-1941-04-26. 
W PS dopisała:

Pisz częściej, bardzo się martwię

Wspomniany nalot bombowy miał miejsce w nocy o godz. 2.10. Z angielskiego samolotu spadła jedna bomba o dużym tonażu w pobliżu dawnego browaru Huggera przy ul. Śniadeckich 12, zniszczyła całkowicie 3 budynki, ciężko uszkodziła 15 domów, a lżej 10. Zginęło 3 Polaków i 17 Niemców, ciężko rannych zostało 12 osób, lekko rannych 30, a blisko 1000 osób bez dachu nad głową ${ }^{36}$. Bombardowanie to dotknęło przede wszystkim niemieckich urzędników i ich rodziny, którzy zajęli mieszkania po przymusowo wysiedlonych Polakach ${ }^{37}$.

Temat wysyłanych matce paczek, braku potwierdzenia ich odbioru, zbyt rzadkiej korespondencji od niej i rosnącego niepokoju przewijał się także w późniejszych kartach pocztowych z maja 1941 roku $^{38}$. W jednej z kartek Wera wyraziła nawet gotowość wzięcia urlopu i przyjazdu do matki ${ }^{39}$. Można przypuszczać, że niepokój o nią był spowodowany nieregularnym otrzymywaniem listów. Żaliła się też, że wciąż nie nadchodzą z Hamburga dokumenty potrzebne dla Kasy Chorych (Krankenkasse) oraz Urzędu Gospodarki (Wirtschaftsamt) potrzebne do załatwienia kartek żywnościowych i odzieżowych.

W czerwcu tegoż roku to ona uspokajała matkę: „nie masz się martwić, jeśli czasem nie piszę, powodzi mi się znakomicie”. Dalej opisała chorobę swojej wspominanej już, a niezbyt przez nią lubianej, koleżanki z pracy i współlokatorki:

Pani W. jest bardzo chora, pewnie będzie musiała pójść do szpitala. [...] Ma spuchniętą twarz i szyję. To gruczoły. Dostała dwa zastrzyki w ramię, ciągle jest półprzytomna z bólu. Dziś powiedziałam o wszystkim jej szefowi, żeby za-

${ }^{35}$ Kartka z fontanną na Königsplatz (pl. Cyryla Ratajskiego), sygn. IV-Vas-1941-05$-08 / 09$.

${ }^{36}$ M. Olszewski, Naloty bombowe zachodnich aliantów na Poznań w 1941 i 1944 roku. Część pierwsza, „Kronika Miasta Poznania” 1967, nr 2, s. 21-22. Inną liczbę ofiar (27-30 zabitych, w tym 18 Niemców, dwa razy wyższą liczbą rannych od zabitych) podał C. Łuczak, Dzień po dniu w okupowanym Poznaniu..., s. 231.

${ }^{37}$ Obraz zniszczeń przedstawiają fotografie w albumie: Okupowany Poznań $i$ Wielkopolska w niemieckich fotografiach $i$ dokumentach (1939-1941): ze zbiorów Instytutu Zachodniego w Poznaniu, red. M. Rutowska, M. Tomczak, Poznań 2005, s. 42-43.

${ }^{38}$ Por. pocztówki z widokiem Leo-Schlageterstr. (ul. Gwarna), sygn. IV-Vas-1941-05-05 i z widokiem Dworca Głównego w Poznaniu, sygn. IV-Vas-1941-05-19.

${ }^{39}$ Widokówka z Biblioteką Raczyńskich na pl. Wolności, sygn. IV-Vas-1941-05-14. 
jął się Kasą Chorych, bo ona ma taki sam kram jak ja z moją. Od kilku dni tutaj jest potwornie zimno i bez końca leje, marznie się jak zimą i nic nie schnie ${ }^{40}$.

Choroba koleżanki była głównym tematem następnych kartek:

Pani W. miała w czwartek 19/6 operowaną twarz. W środę zbadano w szpitalu także mnie, bo obawiano się, że jestem zarażona, ale jestem zdrowa [...]. Dzisiaj po południu W. miała wysoką gorączkę. Siostra oddziałowa powiedziała, że jeszcze długo będzie trwał kryzys, że powinnam sprowadzić córkę ${ }^{41}$.

Lekarz ma nadzieję, że pod koniec tygodnia będzie mógł powiedzieć coś konkretnego [...]. Ona skarży się na siostry, to są bzdury, one wszystkie są miłe. Tylko ona jest właśnie taką niecierpliwą i impertynencką chora, dokładnie taka, jak jest zdrowa. Szpitale są przepełnione, siostry mają i tak więcej pracy niż tylko zajmowanie się nią. Ona leży wciąż w pojedynczym pokoju z napisem „Wstęp wzbroniony"42.

W lipcu Wera wysłała matce ostatnią wiadomość o swej współlokatorce:

Pani W. zasnęła dziś o 8 1⁄2. Szpital mnie wezwał. Córka nawet nie zostawiła adresu. Życzeniem pani W. była kremacja. Tu nie ma takiej możliwości. Wysłaliśmy telegram, czy ona nie powinna być przewieziona. Być może zebrała na to pieniądze. Nie znaleźliśmy żadnych oszczędności. Nie mogę tego zrozumieć. Może wkrótce przyjdzie odpowiedź na telegram. Trumnę i wszystko musimy sami załatwić. Już nie wiem, gdzie mam głowę ${ }^{43}$.

W sierpniu 1941 roku Wera V. wróciła w pocztówkach do matki do dotychczasowych trosk i spraw codziennych:

Wysyłaj częściej kartkę, żebym była spokojna, że nic się nie dzieje. Dzisiaj jest niedziela. Jestem tu na obiedzie ${ }^{44}$, mam na sobie nową jasną sukienkę. Wygląda zachwycająco. W radiu jest moja ulubiona muzyka z „Krainy Uśmiechu”45. Jestem bezgranicznie szczęśliwa. Bardzo podoba mi się tutaj, chociaż praca trwa

${ }^{40}$ Kartka z widokiem ogólnym Mosiny, sygn. IV-Vas-1941-06-13 i 14 (Foto Wimar).

${ }^{41}$ Pocztówka z widokiem cegielni w Mosinie, sygn. IV-Vas-1941-06-21 (Foto Wimar).

${ }^{42}$ Cegielnia w Mosinie z oddali, sygn. IV-Vas-1941-06-25 (Foto Wimar).

${ }^{43}$ Karta pocztowa z widokiem Petriplatz (pl. Wiosny Ludów), sygn. IV-Vas-1941$-07-07$.

${ }^{44}$ Awers kartki przedstawiał Kasyno Miejskie.

${ }^{45}$ Operetka Franza Lehara. 
w istocie bardzo długo. Czy mogłabyś skrócić moją czarną sukienkę w kwiaty na wzór tej żółtej w kwiaty? Tu jest bardzo zimno i już nie czas na jasne sukienki letnie. Halka pasuje świetnie, bardzo się cieszę. Pewnie się nachodziłaś po nią ${ }^{46}$.

W kolejnej kartce napisała:

Bardzo się ucieszyłam z Twojego listu z 18.8. Tapeta jest ładna, sama ją wyszukałaś? [...] Bądź ostrożna w ciemnościach. Znowu uderzyłam się głową w szyld parkingu, ale poza tym powodzi mi się dobrze, tylko pracy bardzo dużo... ${ }^{47}$.

Z powodu problemów z zębami Wera zapowiedziała wizytę u matki:

Koniecznie muszę przyjechać do Hamburga do dentysty. Jeśli facet tutaj nie wywoła zdjęć rentgenowskich, zrobię awanturę. Tu nie pozwolę nic zrobić, nie mam ciepła ani rumianku do płukania [...]. Jak będę miała zdjęcia, wyślę je Tobie. Porozmawiaj potem z dr. Sch. w szpitalu, co on radzi. Można się wściec. Wcale nie mam ochoty jechać, znowu się pakować. Ciocia E. musi poczekać, jeśli mam pilną sprawę do Ciebie, nie mam czasu dla innych. Nocą nie mogę nic zrobić, jak często mam Wam to wyjaśniać? ${ }^{48}$

W kolejnej kartce ucieszyła się z paczki z nową sukienką i napisała o swojej pracy:

Mam teraz jeszcze mniej czasu na pisanie w pracy. Muszę jeszcze stenografować także dla dr. E., który jest zwierzchnikiem mojego szefa. Znowu nowa dziedzina $z$ kwasem fosforanowym [...]. Jeszcze mi huczy w głowie, nie mam o tym pojęcia. Idzie mi jednak dobrze. Nie będę od tego głupsza... ${ }^{49}$.

Sprawa nowych ubrań pojawiała się często w korespondencji Wery V.:

Wysłałam paczkę. Materiał powinien mieć 70\% wełny. Chciałabym go na spódnicę taką jak ta zielona. To są tylko dwa metry. Pojęcia nie mam, czy to starczy. Napisz, co o tym sądzisz. Trzeba brać to, na co się trafi. Właśnie dostali nową belę [...]. Kurt przysłał mi tylko krótkie pozdrowienia z Czarnkowa [...]. W następnym tygodniu dostanę pewnie węgiel. Zrobiłam straszną awanturę, inaczej nic się nie załatwi ${ }^{50}$.

${ }^{46}$ Sygn. IV-Vas-1941-08-10 (Foto Weber).

${ }^{47}$ Kartka z widokiem Piwnicy Ratuszowej na Starym Rynku, sygn. IV-Vas-1941-08-20.

${ }^{48}$ Pocztówka z widokiem Warty, sygn. IV-Vas-1941-09-01.

${ }^{49}$ Kartka z restauracją „Bristol”, sygn. IV-Vas-1941-09-02 (Foto Weber).

${ }^{50}$ Widok z Mostu Teatralnego, sygn. IV-Vas-1941-09-21. 


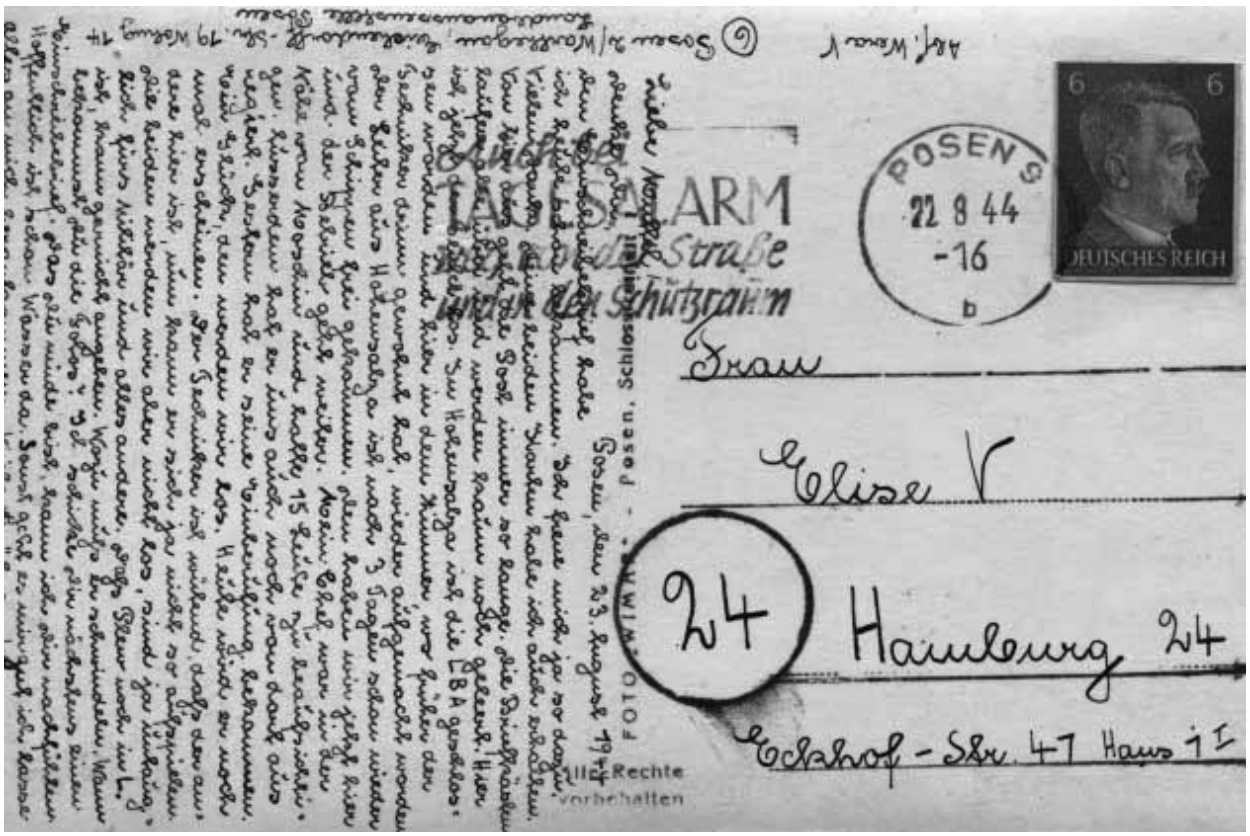

Treść widokówki z 20 sierpnia 1941 roku

Wera troszczyła się również o odzież i obuwie dla matki:

Czy masz już buty? Tutaj są tylko buty ze skóry od 35 marek i więcej. Czy mogłabyś kupić mi pończochy w Alsterhaus ${ }^{51}$ ? Mam jeszcze 27 punktów ${ }^{52}$. To głupio, że nigdy nie wiem, ile materiału potrzeba, kiedy chcę coś kupić. Czy chcesz, żebym Ci coś jeszcze kupiła? Napisz mi, żebym mogła jeszcze szybko się rozejrzeć. Jak Tobie się powodzi? Jesteś zdrowa i czy porządnie się wysypiasz? [...] Jutro znowu muszę iść do dentysty, na dole znów wypadła mi plomba $^{53}$.

${ }^{51}$ Istniejący do dzisiaj dom towarowy w Hamburgu.

${ }^{52}$ W Kraju Warty wprowadzono kartę odzieżową (Reichskleiderkarte) dla ludności niemieckiej 1 grudnia 1940 roku. C. Łuczak, Dzień po dniu w okupowanej Wielkopolsce i Ziemi Łódzkiej (Kraj Warty). Kalendarium wydarzeń 1939-1945, Poznań 1993, s. 105. Poszczególnym artykułom odzieżowym przypisane były punkty, np.: sukienkę można było kupić za 30, płaszcz typu prochowiec lub żakiet za 25, koszulę nocną za 18, pas do pończoch za 8 punktów. Por. H. Focke, U. Reimer, Alltag unterm Hackenkreutz, t. 1: Wie die Nazis das Leben der Deutschen veränderten. Ein aufklärendes Lesebuch, Reinbek 1991, s. 181. Jesienią 1941 roku przydzielono ludności niemieckiej 120 punktów na następny rok, po czym przedłużono je do końca 1944 roku. M. Kitchen, Nazistowskie Niemcy w czasie wojny, Warszawa 1997, s. 95.

${ }^{53}$ Pocztówka z portretem gauleitera A. Greisera, sygn. IV-Vas-1941-09-24 (wyd. Heinrich Hoffmann, München). 


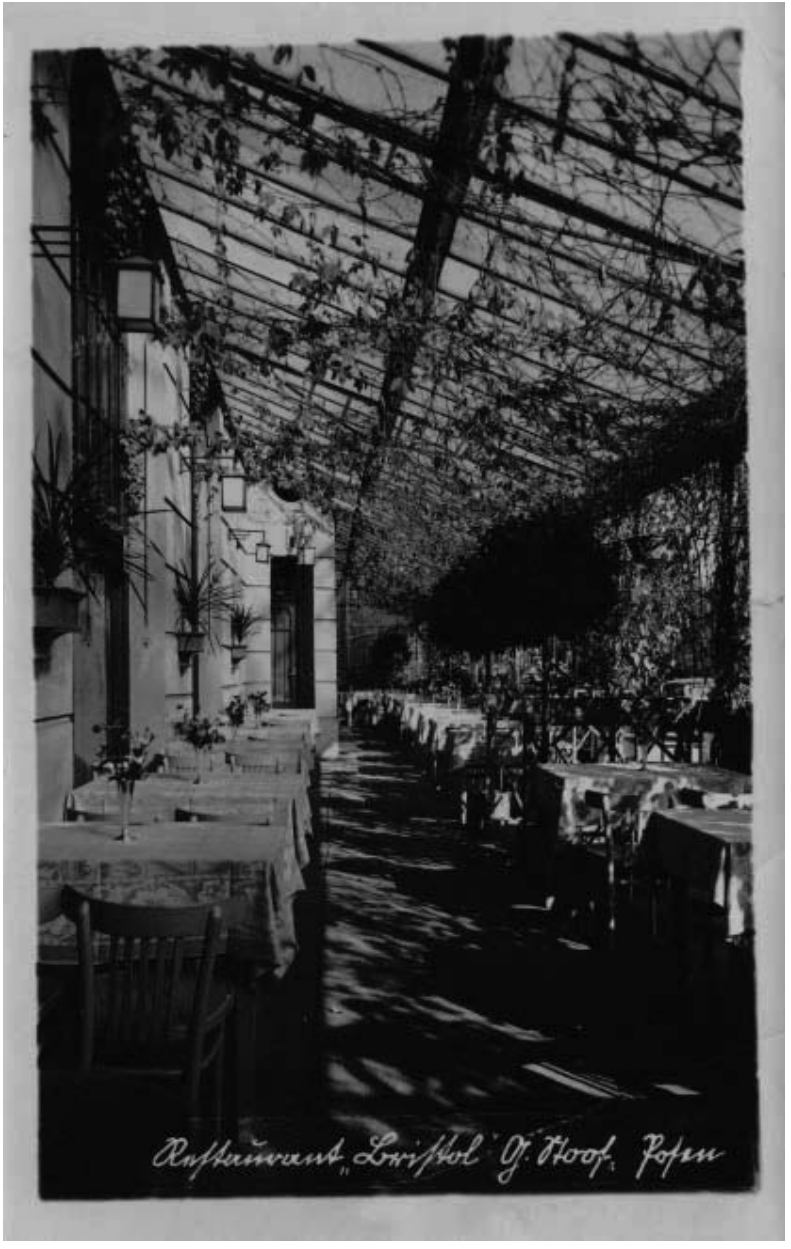

Restauracja „Bristol” (kartka z 2 września 1941 roku)

Wera wysyłała matce nie tylko żywność i rzeczy do wyprania lub przerobienia:

Jest tam ozdobny kafel z herbem Poznania. Oby doszedł cały. Powieś go gdzieś ładnie [...]. Kurt pisze, termin jego powrotu jest tymczasem nieznany ${ }^{54}$.

Pierwszego listopada 1941 roku napisała, że w Poznaniu od dwóch dni padał śnieg. Nalegała na szybką wiadomość, co się dzieje w Hamburgu, bo był wymieniony w wiadomościach radiowych. Poprosiła też o przysłanie ciasta ${ }^{55}$. W kolejnej pocztówce informowała:

${ }^{54}$ Inne ujęcie Piwnicy Ratuszowej, sygn. IV-Vas-1941-09-25.

${ }^{55}$ Kartka z widokiem Martinstraße (ul. Święty Marcin), sygn. IV-Vas-1941-11-01. 
Tutaj jest zima, bardzo dużo śniegu jak u nas na Boże Narodzenie. Od wczoraj pracujemy tylko do $51 / 2$, a w soboty do 1 . Teraz można przynajmniej zrobić jakieś zakupy wieczorem ${ }^{56}$.

Dziesięć dni później pochwaliła się, że udało jej się dostać walonki na talon. Kurt Sch. dopisał:

Tutaj jest strasznie zimno, Pani dziecko jest stale zmarznięte ${ }^{57}$.

Pod koniec listopada Wera miała nadzieję na urlop i wyjazd do Hamburga:

Jeśli jeszcze nie wysłałaś grubych rzeczy zimowych, zatrzymaj jeszcze wszystko. Prawdopodobnie przed świętami przyjadę do Hamburga na urlop [...]. Nie mam kompletnie ochoty na podróż, ale muszę pójść do dentysty. Przyślij mi także mufkę, jest nie do wytrzymania, bo nie mogę włożyć rąk do czarnego płaszcza. Mam na sobie nowy żakiet, który jest bardzo ciepły. Kurt jest znowu w Kutnie [...]. Jeśli się uda, wyjadę 17 lub 18 grudnia... ${ }^{58}$.

Na początku grudnia 1941 roku Wera nie była pewna, czy wyjedzie do Hamburga:

Właśnie usłyszałam, że wstrzymano kursowanie pociągów w czasie 16.12.-5.1. Pewnie nic nie wyjdzie z mojego przyjazdu. Poza tym nie mam jeszcze zgody na urlop specjalny [...]. W czasie 16.12.-1.1. pisz na mój prywatny adres: Schifferstr. 3, wejście 2, mieszkanie $13[\ldots]^{59}$. Kiedy biuro jest zamknięte, nie dostanę poczty ${ }^{60}$.

Dwa dni później zapowiedziała dużą paczkę:

To bardzo pilna sprawa. Gdyby Cię nie było w domu, kiedy ona przyjdzie, musisz wszystko zostawić i natychmiast ją odebrać. Przyjdzie jako pilna z zezwoleniem $^{61}$.

${ }^{56}$ Miejska Kasa Oszczędności w Poznaniu, sygn. IV-Vas-1941-11-05.

${ }^{57}$ Widok ul. Głogowskiej, sygn. IV-Vas-1941-11-15.

58 Pocztówka z Kuhndorfpark (Park Sołacki), sygn. IV-Vas-1941-11-27.

${ }^{59}$ Dzisiaj ul. Szyperska. Wera V. mieszkała pod tym adresem aż do 12 listopada 1944 roku (ostatnia wiadomość od niej).

${ }^{60}$ Dotychczas autorka podawała na kartkach adres siedziby swojego biura: kartka z widokiem budynku NSDAP Gauwaltung Wartheland (dziś stary gmach Uniwersytetu Ekonomicznego). Uderza brak flag nazistowskich na budynku, sygn. IV-Vas1941-12-07.

${ }^{61}$ Najprawdopodobniej Wera wysłała matce paczkę z atrakcyjnymi artykułami świątecznymi, na wywóz których trzeba było otrzymać zezwolenie, i obawiała się kradzieży: kartka z widokiem Reichstatthalterei (Namiestnictwo Rzeszy) i kościoła farnego, sygn. IV-Vas-1941-12-09. 
Wera V. dostała urlop i po powrocie opisała swoją podróż z Hamburga:

To była szalona jazda. Do Berlina w nieogrzewanym pociągu. Jestem potwornie przeziębiona. Jeszcze Ci napiszę, jak dojechałam. Moja walizka dotarła w porządku. Kartka od Ciebie leżała w domu. U mnie jest straszny bałagan. Na godz. 5 kupiłam sobie bilet do kina. W Nowy Rok będę sama i mogę posprzątać. Kurt zaczął dzisiaj swoją karę. 6 dni w ciemnej celi o chlebie i wodzie. Z zimna jeszcze się nie umyłam. Wszystkie sklepy są zamknięte $\mathrm{z}$ powodu inwentury. Tyle na dzisiaj, dużo pozdrowień i wszystkiego dobrego na Nowy Rok... ${ }^{62}$.

Z dalszej korespondencji nie wynika, czym zajmował się Kurt Sch. i za co został ukarany.

Po Nowym Roku życie Wery potoczyło się dawnym trybem:

Ciągle jestem w biegu i nie mam czasu. Dostałam kuchenkę elektryczną, ale na nic mi się nie przydaje. W całym Poznaniu nie ma sznura do niej. Pasuje tylko taki jak do żelazka elektrycznego. Mogłabyś się postarać? Piszę na poczcie znowu w pośpiechu. Muszę kończyć, bo nie dostanę jedzenia. Zaczęłam już list do Ciebie. Włożę go do paczki. Napisz choć raz długi list. Każdego dnia trochę, tak jak ja to robię. Co się dzieje $\mathrm{z}$ moją mufką?... ${ }^{63}$.

W kartkach wymieniała, kto do niej napisał i komu zdążyła odpowiedzieć lub nie, prosiła ją też o radę:

Jeśli chodzi o K., musisz napisać mi w kartce, co powinnam zrobić [...]. Nie wiem, co się dzieje, nie czytam żadnej gazety ${ }^{64}$.

Tego samego dnia dostała pocztę od matki i od razu odpisała:

Gdzie pisałaś? U lekarza? I co nie ma być gorzej? Teraz nie będę spokojna, dopóki nie dowiem się, o co chodzi. A poczta dochodzi tak długo, bo jeździ tak mało pociągów. Wczoraj wieczorem Kurt prawie upadł. Miał tak wysoką temperaturę i zawroty głowy. Boję się, że ma zapalenie płuc. Ja czuję się bardzo dobrze. Tylko nie mogę spać w nocy z powodu pcheł. Mam je w łóżku, zabieram je do biura. Widzę te wielkie skaczące bestie, ale nie mogę ich złapać ani strząsnąć. Jeśli

62 Pocztówka z widokiem Katedry od tyłu, sygn. IV-Vas-1941-12-30.

${ }^{63}$ Kartka z widokiem Schlossfreiheit Str. (ul. Swięty Marcin od ul. Gwarnej w stronę ronda Kaponiera), sygn. IV-Vas-1942-01-15.

${ }^{64}$ Pocztówka z wieżą Zamku (widok zimowy), sygn. IV-Vas-1942-01-29/a. 
wiosną znowu pokażą się jeszcze pluskwy, wścieknę się. Może już mam także jakieś. Nie mogę tego stwierdzić, tak dużo mam opuchnięć i zadrapań. Tymczasem wysłałam Ci paczuszkę. Tutaj jest zimno. Założyłam już ostatnie ubrania ${ }^{65}$.

Problem marznięcia Wera rozwiązała przez kupno nowego płaszcza na kartę odzieżową:

Dokładnie 88,80 i 75 punktów. Przeróbka będzie kosztować jeszcze 2-3 marki. On jest za długi, rękawy też. Wzięłam też figi $=6$ punktów. Dla Ciebie chust$\mathrm{kę}=4$ punkty, został mi jeszcze 1 punkt [...]. Przeszłam dziś przez wszystkie sklepy. Znowu się przewróciłam, jest potwornie ślisko ${ }^{66}$.

Po roku od przybycia Wery V. do Poznania nie zmienił się styl jej korespondencji z matką. Nadal w widokówkach informowała o wysłaniu pieniędzy lub paczki z zakupami artykułów trudno dostępnych w głębi Rzeszy czy przesyłki z praniem, o braku czasu i o codziennych kłopotach:

Dziś po południu wysłałam poleconą paczuszkę z umówionymi rzeczami. Czy nadeszły pieniądze? Właśnie spakowałam dużą paczkę z praniem. Wyślę ją w najbliższych dniach. Proszek do prania wyślę później, zapomniałam go włożyć do środka. Czy mogłabyś wkładać jeden karton w drugi? Trudno je dostać, a ja mam mało czasu na szukanie. Nowy czas pracy wejdzie w życie pewnie od 1.3. Wtedy to koniec. W paczuszce jest list, w którym wszystko napisałam. Od kilku dni znowu nie ma ogrzewania. Co u Ciebie? Mam nadzieję, że z Twoimi rękami jest lepiej [...]. Napisz, jak paczuszka nadejdzie. Może chustka Ci się spodoba.

W kartce znajduje się też zagadkowy dopisek:

Od 15.2. będzie Z., tydzień wcześniej. Pamiętaj o tym ${ }^{67}$.

Nie wiadomo, czy chodziło jej o jakąś osobę, czy o atrakcyjny towar na kartki. W tym wypadku autorka starała się zataić informację przed przypadkowym czytelnikiem.

${ }^{65}$ Widok z Mostu Teatralnego, sygn. IV-Vas-1942-01-29/b.

${ }^{66}$ Autorka pisała tę widokówkę w sobotę, kiedy krócej pracowała i mogła resztę dnia poświęcić na zakupy; karta z widokiem Palmiarni w Parku Miejskim (Park Wilsona), sygn. IV-Vas-1942-01-30 (Verlag Heinrich Hoffmann, Posen).

${ }^{67}$ Widokówka z Collegium Minus, sygn. IV-Vas-1942-02-10. 


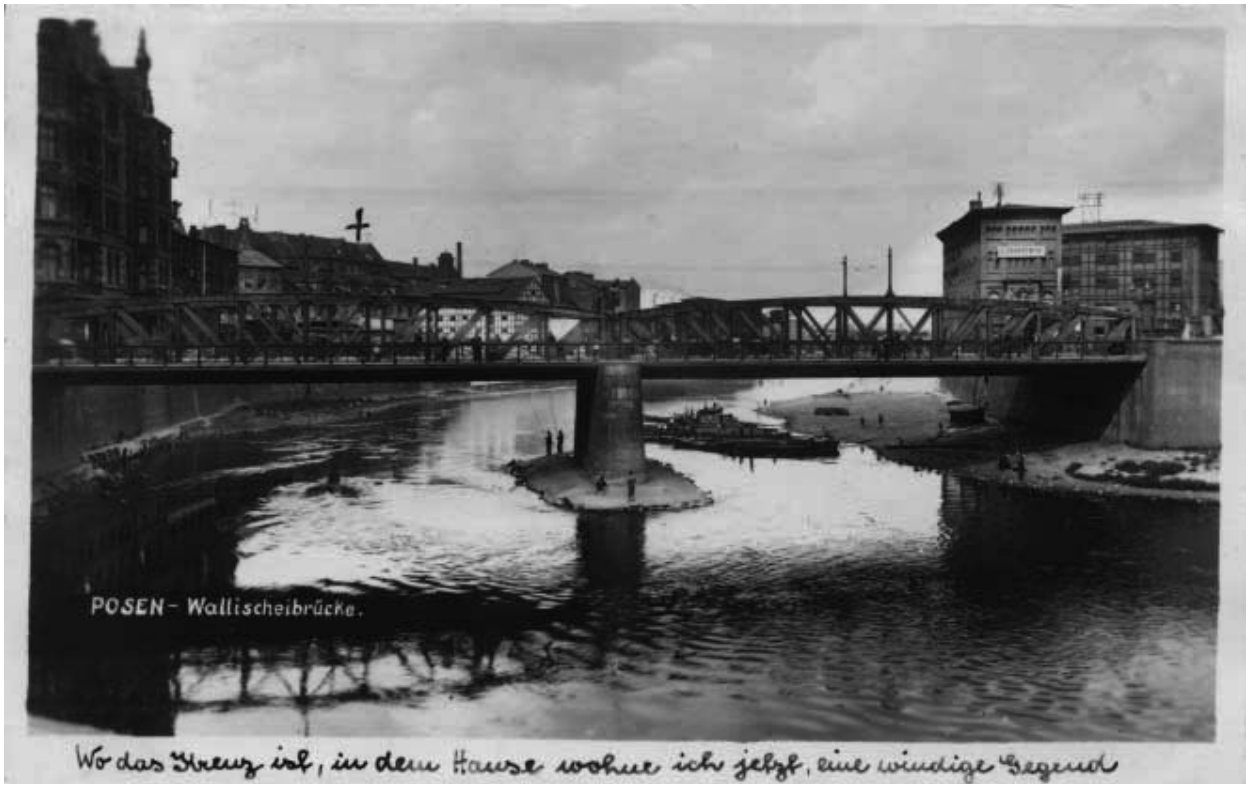

Most Chwaliszewski - krzyżykiem zaznaczone miejsce zamieszkania Wery V. przy ul. Szyperskiej (kartka z 24 lutego 1942 roku)

W następnej widokówce otwarcie napisała, że pod pretekstem wizyty $\mathrm{u}$ dentysty poszła na pocztę wysłać paczkę. W tej samej kartce prosiła matkę:

Nie masz czasem jakiejś starej pokrywki? Nie mogę tutaj dostać. Garnek ma $17 \mathrm{~cm}$ średnicy, może być więc większa, byle by nie wpadała do środka [...]. Mamy Dni Rolnika 14 i 15 lutego. Do teatru pójdziemy 14, a 15 jest nadzwyczajne spotkanie kobiet wsi. Tam na pewno zasnę. Ale nie powinnam. Mój szef idzie na inne posiedzenie i mam mu zdać sprawozdanie, o czym będą tam pleśćc $^{68}$.

Najprawdopodobniej szef Wery z okazji święta wybierał się na spotkanie rolników Kraju Warty z namiestnikiem Rzeszy, Greiserem, który wtedy powiedział: „w odniesieniu do Polaków nie należy kierować się żadnymi sentymentami" 69 .

Pod koniec lutego 1942 roku Wera V. cieszyła się, że były już tylko 3 stopnie zimna:

${ }^{68}$ Zimowy widok Zamku od strony wieży, sygn. IV-Vas-1942-02-12.

${ }^{69}$ Cyt. za: C. Łuczak, Dzień po dniu w okupowanym Poznaniu..., s. 330. 
Można już normalnie oddychać. Przyślesz mi kartki? W restauracji dostanę więcej. Dziś oddałam już jedną kartkę na marzec. Napisz wreszcie więcej. Przygotuj sobie duży arkusz i pisz wtedy, kiedy właśnie będziesz miała czas, każdego dnia trochę, tak jak ja to robię ${ }^{70}$.

W marcu otrzymała upragniony długi list od matki:

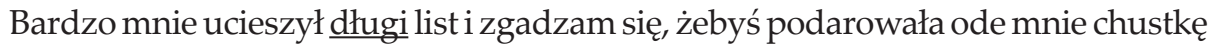
cioci E. [...] Dobrze, że znowu smakuje Ci jedzenie. Właśnie włożyłam do skrzynki list do Ciebie. Odpowiem Ci jeszcze obszerniej na wszystko, o czym pisałaś ${ }^{71}$.

Narzeczony Wery, Kurt Sch., dopisał pozdrowienia. Tydzień później Wera ucieszyła się z mufki:

Tutaj pada śnieg i wieje, ale chwilowo nie jest już tak całkiem zimno. Dotąd mamy stary czas pracy [...]. Poza tym nic nowego. Wszystko napisałam w liście. Pozdrów ode mnie ciocię E. Czy moja kartka urodzinowa dotarła na czas?

\section{Z innej strony widokówki dopisała:}

To miejsce zostawiłam dla Kurta, ale go nie spotkałam. Weź, proszę, dla niego na Wielkanoc paczuszkę lekkiego, ale dobrego tytoniu. Nie mam innego pomysłu, co by mu podarować ${ }^{2}$.

Narzeczony dopisał się na następnej kartce:

Wiele pozdrowień, jesteśmy właśnie po obfitej kolacji ${ }^{73}$.

Rzeczywistość wojenna zakłóciła spokój Wery V.:

Jeśli teraz piszę niezbyt często, nie powinnaś się niepokoić. Nie mam teraz czasu, siedzę w tej chwili w przedpokoju u dr. E [...]. Wszyscy krzyczą i są nerwowi z powodu wielu powołań do wojska. Nie wiem, dla kogo mam najpierw pisać. W Wielkanoc będziemy pracować aż do ostatniej minuty. Jeśli dostaniesz tylko 1 jajko, zaczekaj z ciastem aż będzie ich więcej [...]. Kurt jest już 3. dzień $\mathrm{w}$ drodze, prawdopodobnie w Lesznie ${ }^{74}$.

${ }^{70}$ Kartka z widokiem na Most Chwaliszewski z dopiskiem: „,mieszkam teraz w tym domu - tam, gdzie jest krzyżyk, bardzo wietrzna okolica”, sygn. IV-Vas-1942-02-24.

${ }^{71}$ Widok zimowy na Stadtheater (gmach Opery), sygn. IV-Vas-1942-03-03.

${ }^{72}$ Restauracja w Stadtpark (Park Wilsona), sygn. IV-Vas-1942-03-11.

${ }^{73}$ Wilhelmplatz (pl. Wolności) - widok z góry, sygn. IV-Vas-1942-03-21.

${ }^{74}$ Opera i park w szacie zimowej, sygn. IV-Vas-1942-03-25. 


\section{Wielkanoc spędziła w Poznaniu:}

Czy dotarła moja kartka wielkanocna? Nie dostałam ani jednej. Siedzimy teraz w bardzo wytwornym lokalu „Boschers Weinstuben”, ale niestety jest tylko piwo. Kurt chce mnie zdenerwować, mówi, że pojedzie do domu o godz. 9.00, ale ja nie pozwolę się denerwować.

\section{Narzeczony dopisał:}

$\mathrm{Z}$ tym denerwowaniem przeze mnie nie jest całkiem tak. Pani córka jest bardzo zmęczona i chciałbym, żeby odpoczęła ${ }^{75}$.

\section{Zimno dokuczało także w drugiej połowie kwietnia:}

Dzisiaj po raz pierwszy jest trochę cieplej, ale w pokoju jeszcze przeraźliwie zimno. Ze złości już nie kupię węgla, bo przeklęta hołota wykradła mi ostatni cetnar, który sobie zamówiłam, prawie w całości. Już nie sprząta się w ogóle. Jak ostatnio wyjęłam z szafy ciemnoniebieską sukienkę, najchętniej rozbeczałabym się, całkiem zabrudzona. Tak jest z wszystkimi rzeczami. Kurz i tylko kurz [...]. O Kurcie nie mogę powiedzieć nic dobrego. W środę byliśmy w Operze. On ma wyrzuty sumienia, stąd ta niespodzianka ${ }^{76}$.

\section{Czas pracy wydłużył się również w maju:}

Właśnie poinformowano nas, że także w pierwszy dzień Zielonych Świątek będziemy pracować od 9.00 do 13.00. Wszyscy przeklinają i wymyślają. Napisz mi, jak to wygląda w starej Rzeszy. Dzisiaj jest piątek i paczki jeszcze nie ma. Właśnie przyszła ostatnia poczta. Dla mnie nic nie ma. Pies z kulawą nogą nie przysłał mi karki z okazji Zielonych Świątek. Wczoraj wysłałam małą paczuszkę polecona.. Kto wie, kiedy i jak ona dotrze [...]. Od Kurta nie mam jeszcze żadnej wiadomości z Rosji ${ }^{77}$. Dostałam bon na buty letnie, ale z gumowymi podeszwami. Wzięłam biało-niebieskie. Naturalnie są z materiału, ale bardzo ładne. Dostaliśmy 20 jaj na kartki ${ }^{78}$.

${ }^{75}$ Wera V. była naprawdę zmęczona w ten Wielkanocny Poniedziałek, bo pomyliła się w dacie i napisała 1941 zamiast 1942 rok, na który wskazuje stempel pocztowy. Kartka z widokiem gmachu Izby Przemysłowo-Handlowej, w którym znajdowały się również biura Stowarzyszenia Rolników (okna po lewej stronie) przy ul. Mickiewicza, sygn. IV-Vas-1942-04-06 (wyd. „Aquila” Kom.-Ges. Posen).

${ }_{76}$ Zamek od strony wschodniej (widok zimowy), sygn. IV-Vas-1942-04-18.

${ }^{77} \mathrm{~W}$ tej kartce Wera wspomniała po raz ostatni Kurta. Być może pisała o nim jeszcze w listach do matki.

${ }^{78}$ Stary Rynek (widok od strony podcieni), sygn. IV-Vas-1942-05-22. 
Izba Przemysłowo-

-Handlowa - siedziba Stowarzyszenia Rolników Kraju Warty miejsce pracy Wery $\mathrm{V}$. (kartka z 6 kwietnia 1942 roku)



Warunki życia codziennego też się pogorszyły:

W tej chwili czekam w łaźni. Nigdy nie ma wody od 7 rano do 9 1 1 2 wieczorem. Cały dzień nie można umyć rąk i toalety się przelewają. Świństwo. Nic dziwnego, jeśli wybuchną tu wszelkie możliwe choroby. W łaźni płynie tylko trochę wody. Czekam już dwie godziny tak dużo ludzi. Znowu nie uda mi się kupić chleba. Tego lata chyba nigdy nie będzie ciepło. Wciąż jeszcze nie można nosić cienkiej bielizny ${ }^{79}$.

${ }^{79}$ Reiffeisenallee (ul. Szelągowska), sygn. IV-Vas-1942-06-07 (B. Cichosz K.V. W. Seyfart-Molkenbuhr Posen). 
Obok problemów z woda, zimnem, brudem, zakupami, bólem zębów, wydłużonym czasem pracy pojawiły się nowe związane z nasileniem się alianckich nalotów bombowych na północne i północno-zachodnie Niemcy - obowiązek uczestnictwa w obronie przeciwlotniczej (Luftschutz):

Od Obrony Przeciwlotniczej dostałam już trzecie wezwanie ${ }^{80}$.

Nawet w godzinach pracy przeprowadzane były ćwiczenia:

Właśnie mieliśmy próbny alarm w obecności policji,

ale bardziej pochłaniał Werę planowany urlop wypoczynkowy (jeśli go dostanie) i perturbacje związane z podróżą:

Jeśli przyjadę, skorzystam z pociągu dla urlopowanych z frontu o 8.50 przez KrzyżSzczecin. Jeśli on przejedzie, powinien być o 19.43 w Hamburgu. Wtedy będę już w niedzielę wieczorem na miejscu. Trzymaj kciuki, żebym mogła wyjechać. Na jazdę przez Berlin trzeba mieć zezwolenie. Bez przesiadki jest wygodniej. Będzie niezły ścisk, bo tu będą podstawione tylko 4 wagony dla osób cywilnych ${ }^{81}$.

Wera musiała otrzymać zgodę na urlop znacznie później, bo wracała $\mathrm{z}$ niego $\mathrm{w}$ połowie sierpnia:

Dobrze dojechałam. Siedzę teraz w poczekalni i już wchłonęłam danie dnia. Wcale nie mam ochoty jechać do domu, bo w radio jest taka piękna muzyka. Jeśli mój pokój jest zamknięty, musiałabym tak czy siak zerwać Polaczków z łóżek, bo oni szybko idą do wyrka ${ }^{82}$.

Autorka użyła pogardliwego określenia Polacken, dalekiego od podziwu dla polskiego szewca z początku swego pobytu w Poznaniu, ale jednocześnie nie chciała ich budzić. W Poznaniu zaczęły dokuczać nocne alarmy:

Jest godz. 24 1/2. Piszę podczas alarmu. Strzelano już, zanim zawyła syrena. Jeszcze nie spałam. Nie mogłam z powodu pluskiew. Moje całe łóżko się rusza

${ }^{80}$ Wilhelmplatz, sygn. IV-Vas-1942-06-08 (Verlag Heinrich Hoffmann, Posen).

${ }^{81}$ Wejście niemieckich oddziałów do Poznania, sygn. IV-Vas-1942-07-15 (wyd. „Aquila" Kom.-Ges. Posen).

${ }^{82}$ Pocztówka z widokiem Wallischeibrücke (już nieistniejący Most Chwaliszewski), sygn. IV-Vas-1942-08-14. 
[...]. Środki nie działaja, a Polaczkowie nic z tym nie robią. Bladzi i drżący polecieli do piwnicy. Też ubrałam się bardzo szybko. Teraz ktoś dzwoni, pewnie chce mnie sprowadzić. Nie ruszę się stąd. Poza tym jest spokojnie [...]. W Szczecinie znowu coś się działo. Jest już po $1 \frac{1}{12}$ i po odwołaniu alarmu ${ }^{83}$.

Po urlopie Wera V. podawała już inny adres swego biura - Liebigstr. 4 (ul. Artura Grottgera), nie wyjaśniając powodu tej zmiany. Walka z pluskwami coraz bardziej zaprzątała jej uwagę:

Na pluskwy pomoże już tylko gazowanie całego mieszkania, bo one już są wszędzie. Ale to trwa $48 \operatorname{godzin}^{84}$.

W miarę upływu czasu Wera tylko napomykała, że otrzymała kartkę od matki, rzadziej wysyłała paczki. Częściej pisała o pracy:

Dzisiaj zniesiono $\mathrm{u}$ nas od zaraz obowiązek pracy w niedzielę. Jednak znowu bąka się o nowym czasie pracy: każdego dnia od 9 do 16, także w sobotę i niedzielę. Od 2 dni jest bardzo zimno. Strasznie marzniemy w biurze. Dopiero pokazali się w budynku zduni. Dr mówi, że zanim oni dotrą do nas na górę, będzie Boże Narodzenie, a zanim piece wyschna, będzie wiosna [...]. Tymczasem zostałam zwolniona z Obrony Przeciwlotniczej... ${ }^{85}$.

Pod koniec października 1942 roku po raz kolejny zmienił się adres biura na Eichendorff - Str. 19 (ul. Szamarzewskiego). W korespondencji pojawił się temat rosnących trudności z zaopatrzeniem i zakupami:

Wczoraj zapisałam się już na wódkę na Boże Narodzenie. Potem stałam prawie 2 godziny w innym sklepie. Dzisiaj rano stałam godzinami po bon na buty zimowe [...], a teraz widzę, że brak na nim podpisu i stempla. W biurze konamy ze strachu [...]. W sobotę zostanie powołany doktor, szkoda... ${ }^{86}$.

Na początku grudnia Wera wysłała matce pocztą polową życzenia z okazji urodzin i Nowego Roku z braku pewności, czy dostanie wolne na święta ${ }^{87}$. Mimo że wyjaśniła się sprawa urlopu, pozostała kwestia kursowania pociągów:

${ }^{83}$ Bamberka, sygn. IV-Vas-1942-08-18/19 (Foto Weber).

${ }^{84}$ Dr. Wilmsstrasse (ul. Jana Matejki), sygn. IV-Vas-1942-08-31.

${ }^{85}$ Dworzec Główny od strony torów, sygn. IV-Vas-1942-10-10.

${ }^{86}$ Stary Rynek z fragmentem Ratusza, sygn. IV-Vas-1942-10-27.

${ }^{87}$ Wysyłając wcześniej życzenia, autorka ominęła zakaz wysyłania kartek świątecznych, który obowiązywał od 18 grudnia 1942 do 5 stycznia 1943 roku. C. Łuczak, 
Mój urlop zaczyna się 18 grudnia w południe. Dla mnie to już za późno. Nie będę miała połączenia, a od 19 grudnia wstrzymano ruch pociągów. Spróbuję, nic tutaj nie mówiąc, pojechać pociągiem dla urlopowanych żołnierzy frontowych przez Szczecin. Bez bagażu tak jak stoję. Pociąg wyjeżdża już o 7.25, a więc godzinę wcześniej niż latem. Przez Berlin jadą tylko dwa pociaggi ze złym połączeniem. To zbyt niepewne. Jeśli nie wyjadę z Berlina i zacznie obowiązywać zakaz ruchu pociągów, co wtedy. Noclegu nie dostanę. Nie pisz więc do mnie więcej, tylko trzymaj kciuki. Jestem wykończona zakupami. Z powodu paru drobiazgów trzeba stać godzinami i się łłoczyć. Tu nikt nie staje w kolejce ${ }^{88}$.

Namiestnik Rzeszy w Kraju Warty wprowadził, dzień przed napisaniem tej kartki, zakaz podróżowania od 15 grudnia 1942 do 4 stycznia 1943 roku z okazji świąt Bożego Narodzenia ${ }^{89}$. Nie można odpowiedzieć na pytanie, czy Wera złamała ten zakaz, z powodu luki w kolekcji kartek od połowy grudnia 1941 roku do 20 lutego 1943 roku.

W trzecim roku pobytu w Poznaniu i korespondencji z matką obok informacji o otrzymanej i wysłanej poczcie pojawia się coraz więcej odwołań do zmieniającej się rzeczywistości wojennej:

Od 15 lutego znów wprowadzono obowiązek pracy w niedzielę. W naszej firmie nie było jeszcze komisji generała Unruh ${ }^{90}$. Panna Z. także mi pisała, że w Zarządzie wytypowano już 30 [pracowników - D.M.], a ma być 200 [...]. „Mały alarm” także tutaj jest każdej nocy ${ }^{91}$. Mojemu szefowi urodziła się druga dziewczynka. Prawdopodobnie pójdę dzisiaj do Teatru Miejskiego. To nie przedstawienie tylko próba generalna ${ }^{92}$ przed jutrzejszym dniem ${ }^{93}$.

Dzień po dniu w okupowanym Poznaniu..., s. 415. Pocztówka z wnętrzem jakiejś restauracji, sygn. IV-Vas-1942-12-06.

${ }^{88}$ Budynek Dyrekcji Kolei, sygn. IV-Vas-1942-12-12.

${ }^{89}$ C. Łuczak, Dzień po dniu w okupowanym Poznaniu..., s. 413.

${ }^{90}$ Komisja generała Walthera von Unruh zajmowała się przeglądem kadr urzędniczych pod kątem przydatności na froncie, co prowadziło do redukcji zatrudnienia w administracji państwowej i licznych powołań do Wehrmachtu. Z. Lasak, Kilka uwag o działalności Komisji generata von Unruh na Ślasku (1943-1944), „Biuletyn Głównej Komisji Badania Zbrodni Hitlerowskich w Polsce" 1977, nr XXVII, s. 123-124; W. Porzycki, op.cit., s. 76.

91 „Mały alarm” składał się z trzech krótkich sygnałów ostrzegawczych, które oznaczały zbliżające się samoloty, ale nie spodziewano się ataku bombowego i nie było przymusu schodzenia do schronów przeciwlotniczych. M. Kitchen, Nazistowskie Niemcy w czasie wojny..., s. 106.

${ }^{92}$ Następnego dnia (21 lutego) odbyła się prapremiera sztuki Justa Scheua Ein guter Jahrgang (Dobry rocznik). C. Łuczak, Dzień po dniu w okupowanym Poznaniu..., s. 437-438.

${ }^{93}$ Kartka została dobrana do ostatniego zdania: widok Stadttheater (Teatr Miejski) z lotu ptaka, sygn. IV-Vas-1943-02-20. 
Alarmy przeciwlotnicze stawały się coraz dotkliwsze:

Jest trochę po 23.00! Jeszcze się tłukłam, bo muszę opróżnić walizkę na wyjazd do Inowrocławia, potem idę spać. Nic z tego. Alarm. Mam nadzieję, że nic się nie wydarzy. Napisz do mnie znowu szybko. W przeciwnym wypadku będę się martwić, co się dzieje w Hamburgu. Dzięki Bogu, znowu tylko ostrzeżenie, jest tuż przed 24.00. Teraz szybko do łóżka. Jeśli to tylko będzie możliwe, wyślę Ci małą paczkę ${ }^{94}$.

Kolejna luka w kolekcji pocztówek sięga do lipca 1943 roku. Wera szybciej niż w poprzednim roku otrzymała urlop wypoczynkowy. Wróciła 5 lipca i zaraz po przyjeździe, jeszcze z poczekalni, napisała do matki:

Podróż mi się nie dłużyła, bo była bardzo urozmaicona. Nieustannie trwały krzyki, kłótnie i ścisk [...]. Do toalety nie można było się dostać z powodu przepełnienia [...]. Spotkałam tu niektóre osoby z biura na Hohenzollernstr. ${ }^{95}$.

Następnego dnia musiała usłyszeć wiadomość o kolejnym ataku bombowym na Hamburg, bo pełna niepokoju pytała:

Czy dostałaś mój telegram? Napisz do mnie chociaż parę linijek. Mam nadzieję, że jesteś zdrowa. Czy mam przyjechać? Niepewność co do Twego samopoczucia czyni mnie całkiem nieszczęśliwą [...]. W czwartek nasz dom jeszcze stał... ${ }^{96}$.

Mimo że do tej pory Hamburg był bombardowany 137 razy, najstraszliwsze naloty alianckie pod kryptonimem "Gomora" odbyły się między 24 lipca a 2 sierpnia 1943 roku $^{97}$. Po nalocie w nocy z 24 na 25 lipca Wera prosiła:

Napisz mi, proszę, natychmiast, że Tobie się nic nie stało. Umieram ze strachu. Według radia musiało być źle. Oby to się wreszcie skończyło. Nie odkładaj pisania. Z nerwów nie mogę w pracy zebrać myśli ${ }^{98}$.

${ }^{94}$ Widok poznańskiej łaźni miejskiej, sygn. IV-Vas-1943-03-16.

${ }^{95}$ Pocztówka z widokiem Ritter-Schänke (Karczma Rycerska) na Ritterstr. 2 (ul. Ratajczaka), sygn. IV-Vas-1943-07-05.

${ }^{96}$ Widok Kaiser Friedrich Museum od tyłu, Veit-Stoss-Straße (ul. Ludgardy), sygn. IV-Vas-1943-07-06.

${ }^{97}$ M. Kitchen, Nazistowskie Niemcy..., s. 108-109.

${ }^{98}$ Inne ujęcie wnętrza Karczmy Rycerskiej, sygn. IV-Vas-1943-07-25. 


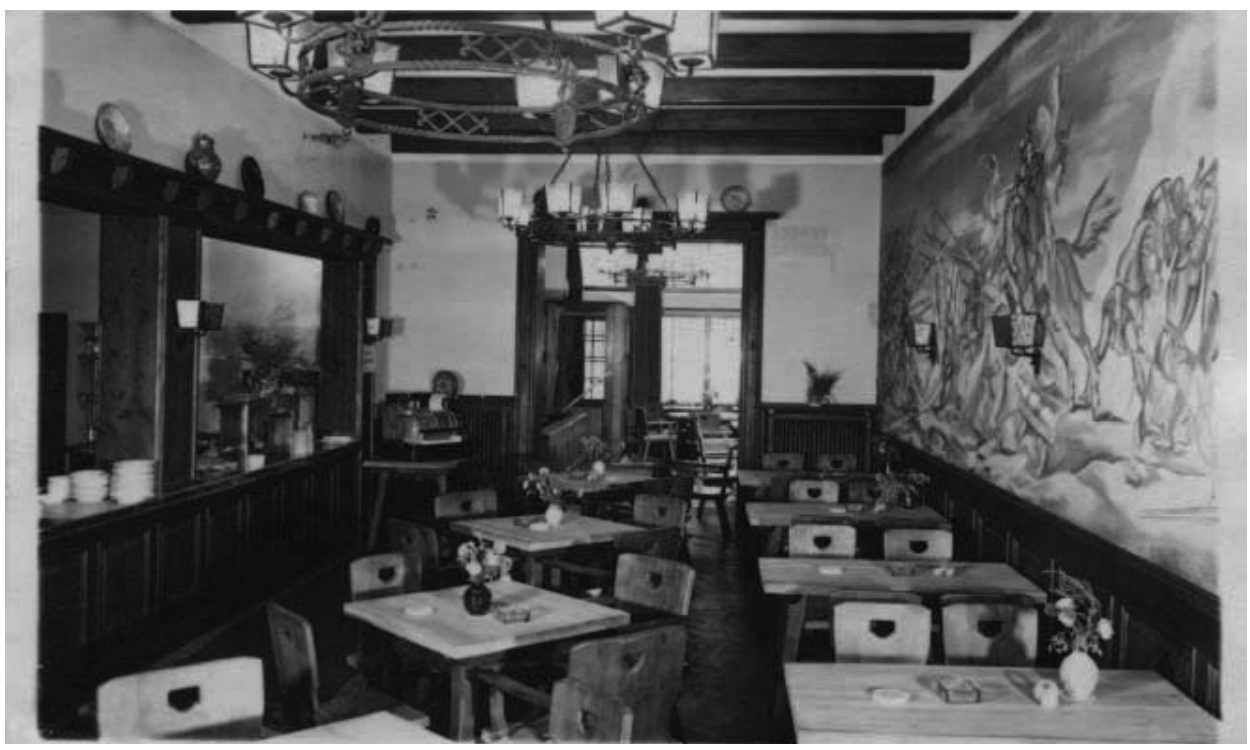

Karczma Rycerska (kartka z 25 lipca 1943 roku)

Poczuła ulgę, kiedy dwa dni później dostała list od matki:

Bogu dzięki, że od razu napisałaś. Ale napisz natychmiast, czy po południu $\mathrm{w}$ niedzielę wszystko dobrze poszło. Jestem w strachu. Podobno był jeszcze nalot w dzień. Kilka słów wystarczy. Możesz wysłać bez znaczka, jeśli akurat nie masz. Żebym tylko wiedziała, czy Ty jeszcze żyjesz. Kiedy ten strach się skończy ${ }^{99}$.

Strach o matkę był uzasadniony. Poprzedni nalot wywołał pożar, który ugaszono dopiero 26 lipca. Już po napisaniu wspomnianej widokówki, w nocy z 27 na 28 lipca miał miejsce jeszcze bardziej zmasowany atak alianckich bombowców, który spowodował burzę ogniową i huragan. Tym razem wybuchł pożar na niespotykaną wcześniej skalę. Kolejne naloty 30 lipca i 2 sierpnia spowodowały ogromne zniszczenia, ale nie wywołały ognia ${ }^{100}$. Bilans strat był bardzo wysoki: 45 tysięcy zabitych i 37 tysięcy rannych, 900 tysięcy osób straciło dach nad głową. Dwie trzecie mieszkańców uciekło z Hamburga do okolicznych wsi ${ }^{101}$. Matka Wery też opuściła miasto, ponieważ widokówka, którą Wera wysłała do niej 10 sierpnia, była zaadresowana na miejscowość Ratzeburg:

${ }^{99}$ Teatr Miejski z lewej strony, sygn. IV-Vas-1943-07-27.

${ }^{100}$ M. Kitchen, Nazistowskie Niemcy..., s. 109.

${ }^{101}$ M. Burleigh, Trzecia Rzesza. Nowa historia, Warszawa 2002, s. 783. 
Jesteś chora? Proszę, napisz mi, jak Ci się wiedzie. Umieram tu z niepewności. Spędzam połowę nocy na dworcu [...], bo wciąż myślę, że może jesteś w którymś transporcie ${ }^{102}$. Wszystkie, które do tej pory przybyły z Hamburga 24, pojechały dalej. Nie mogę więc nikogo znaleźć i zapytać. Pracuje mi się bardzo źle, bo myślę tylko o Tobie i jestem pełna niepokoju ${ }^{103}$.

We wrześniu 1943 roku Wera pisała do matki już na stary adres w Hamburgu:

Dziękuję za kartkę. Dostałam ją dziś po południu. Każdego dnia czekałam na listonosza do 5.00 godz., ponieważ znowu się niepokoiłam, bo Ty nie pisałaś już od 10.9. Chwała Bogu, że znów jest spokój w mieszkaniu. Dostałam mój ryż. Jak szybko robi się teraz ciemno. Myślę wciąż o Tobie, jak Ty znajdujesz drogę w tej ciemności. Jestem znów zrozpaczona, bo tutaj też nie ma żadnego oświetlenia. Jak wczoraj krótko po godz. 20.00 wracałam z jedzenia, było tak ciemno, że znowu wylądowałam na kopie piasku, który jest wszędzie przed drzwiami [...]. Tutaj jest bardzo zimno. Noszę w tej chwili niebieską spódnicę i żakiet w kratkę, które ostatnio zabrałam, pasują całkiem dobrze. Zaraz idę na kolację, a potem do kina, ponieważ tam jest chociaż trochę cieplej ${ }^{104}$.

Korespondencja z Hamburga zaczęła docierać częściej do Poznania:

Dostałam wczoraj kartkę od Ciebie. Mam nadzieję, że nasz dom też wkrótce będzie miał wodę i światło. Dzisiaj po południu zrobiłam sobie wagary. Właśnie widziałam Göbbelsa, dr. Leya itd. [...]. Oszczędzam pranie i sama sobie piorę wszystkie lumpy, bo Ty przecież nie masz wody. Pogoda jest dziś wspaniała, zaraz pójdę do wesołego miasteczka i pojeżdżę karuzelą ${ }^{105}$.

Tego dnia odbywało się w Poznaniu spotkanie Heinricha Himmlera z kierownictwem NSDAP i gauleiterami z całej Rzeszy ${ }^{106}$. Autorka nie wyjaśniła, w jakich okolicznościach ich widziała. Może na ulicy podczas wspomnianych wagarów?

${ }^{102}$ Wielu mieszkańców Hamburga z powodu ogromnych zniszczeń miasta zostało przymusowo ewakuowanych. M. Burleigh, Trzecia Rzesza..., s. 785.

${ }^{103}$ Widok ogólny Poznania, sygn. IV-Vas-1943-08-10.

${ }^{104}$ Sklep z niemieckim rękodziełem, Leo-Schlageter-Str. (ul. Gwarna), sygn. IV-Vas-1943-09-22 (Foto-Gerda Hofmann).

${ }^{105}$ Stary Rynek - widok na fontannę, sygn. IV-Vas-1943-10-06 (Foto Weber).

${ }^{106}$ C. Łuczak, Dzień po dniu w okupowanym Poznaniu..., s. 479-480. 


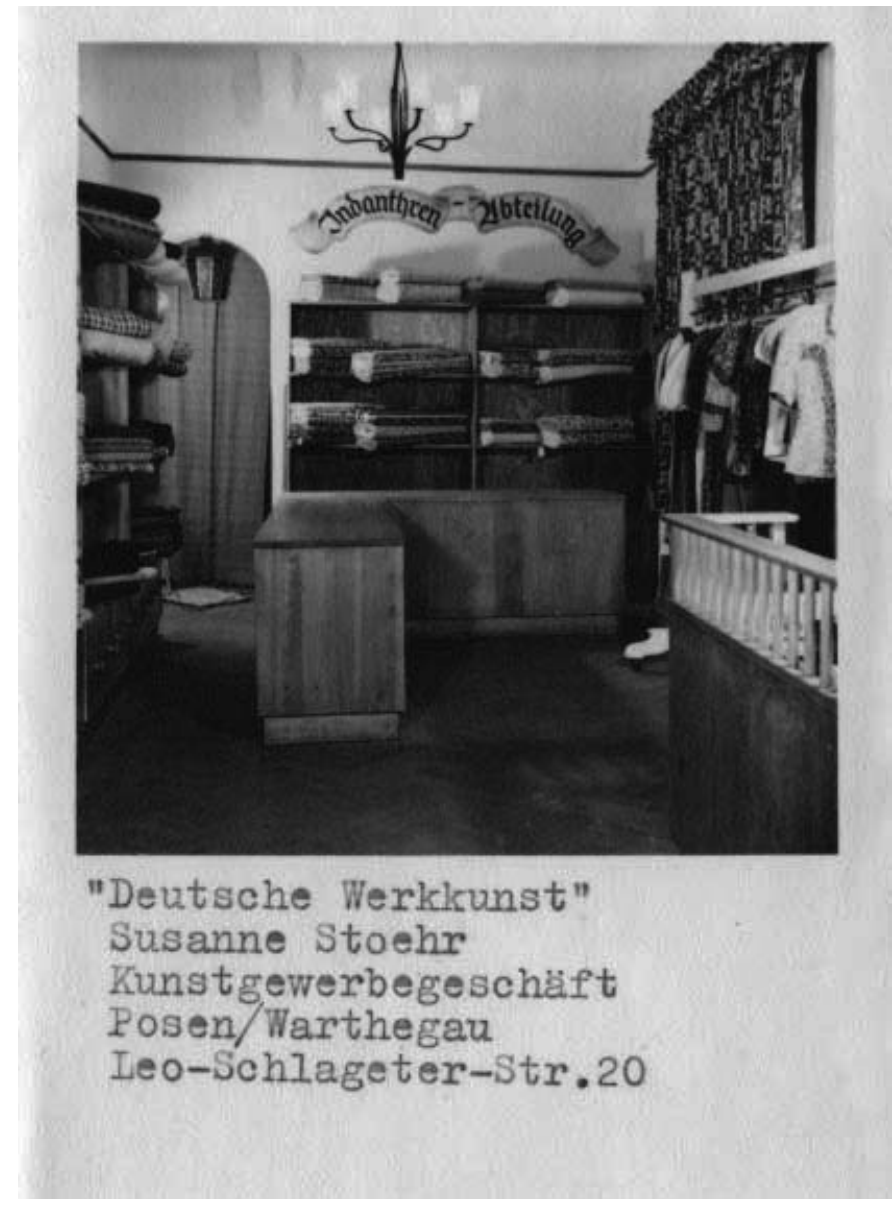

Sklep z rękodziełem - ul. Gwarna (kartka z 22 września 1943 roku)

Życie w Hamburgu powoli wracało do normy, bo Wera dostała od matki paczkę 1 listopada. Córka powróciła do opisywania zdobywania reglamentowanych towarów:

Byłam właśnie w Urzędzie Gospodarki i odebrałam talon na buty zimowe. Dostałam go od razu. Dzisiaj po południu udam się na poszukiwania. W rachubę wchodzą tylko czarne albo granatowe, żadne dwukolorowe. Dziś w południe mieliśmy alarm [...]. Tutaj jest bardzo zimno. Mam nadzieję, że nie będziecie mieli dużo alarmów ${ }^{107}$.

${ }^{107}$ Reichsuniversität (Uniwersytet Rzeszy) - widok auli, sygn. IV-Vas-1943-11-01 (Foto Weber). 
Jeszcze dłużej niż w ubiegłym roku córka nie wiedziała, czy pojedzie na święta Bożego Narodzenia do Hamburga:

Nie możesz liczyć na mój przyjazd. Na moje podanie nie dostałam do dziś odpowiedzi. Jeśli nie przyjadę do 24 grudnia, to znaczy, że nie mogłam przyjechać i nie masz dłużej czekać. To będą smutne święta bez niczego, ale co mogę zrobić [...]. Mam mniejsze bóle uszu, ale za to znowu mam bóle gardła, nerek i reumatyzm w łokciu. Nic dziwnego, ciepło już nie będzie. W mojej budzie jest tak wilgotno, że wszystkie rzeczy są prawie mokre, łóżko też [...]. Mam na sobie tak dużo ciuchów jak całkiem stara kobieta. W całym moim życiu jeszcze tak nie marzłam, nawet w zimną zimę ${ }^{108}$.

Wera zdobyła zgodę na wyjazd na święta do Hamburga ${ }^{109}$ :

Dokładnie o godz. 24 wjechał tutaj pociąg. Do $15 \mathrm{~km}$ przed Poznaniem wlekł się, potem stanął, zepsuła się lokomotywa. [...] Jest godz. $1 \mathrm{w}$ nocy i dopiero teraz dostałam moje piwo. Nie mogłam wytrzymać z pragnienia. Jedzenia już nie ma. Tu panuje duży ruch. $Z$ trudem znalazłam miejsce w poczekalni 3. klasy. Straszny zaduch i słabe światło, a teraz muszę dalej iść pieszo [...]. Leje strumieniami ${ }^{110}$.

Rozpoczęcie czwartego roku pobytu w Poznaniu nie zostało odnotowane w korespondencji Wery. Najważniejsze były dla niej wiadomości od matki, żyła jej problemami, cieszyła każda wiadomość:

Tak bardzo czekałam na pocztę od Ciebie. Ty za dużo pracujesz, inni, którzy są młodsi może o 30 lat, siedzą pod piecem i nic nie robią. Co się stanie, jak zachorujesz? [...] Nie mam rękawiczek, jeśli nie leżą w kuchni, zostały mi tutaj skradzione. Niebieskie skarpetki też nigdy się nie znalazły. Bardzo potrzebny mi czarny kitel. Czy w domu znajdzie się 1 koszula nocna? Bardzo cieszę się na mufkę [...]. Też się cieszę, że robi się jaśniej, znowu upadłam i dość mocno rozbiłam sobie prawe kolano. Często myślę o Tobie. Mam nadzieję, że nic się Tobie nie przydarzy w ciemności ${ }^{111}$.

W Poznaniu, zdaniem Wery, sytuacja była poważna i zamierzała odesłać jeden kufer:

108 Park Miejski, sygn. IV-Vas-1943-12-17.

${ }^{109}$ Od 15 grudnia 1943 do 3 stycznia 1944 roku Niemcy z Kraju Warty musieli mieć pisemne zezwolenie na podróż w okresie świątecznym. Por. C. Łuczak, Dzień po dniu w okupowanym Poznaniu..., s. 492.

${ }^{110}$ Kościół farny, sygn. IV-Vas-1944-01-03 (Foto Weber).

${ }^{111}$ Pocztówka bez opisu, fragment Collegium Minus, w oddali gmach Opery, sygn. IV-Vas-1944-02-09. 




Treść widokówki z 23 sierpnia 1944 roku

W ubiegły czwartek w południe od $1 \frac{1}{2}$ do $2 \frac{1}{2}$ wszyscy siedzieli w piwnicach. Byliśmy gotowi do wyjścia, ale zostaliśmy w biurze. O pracy oczywiście nie było mowy. Dotąd było znowu spokojnie ${ }^{112}$.

Alarmy powtarzały się coraz częściej. W Niedzielę Wielkanocna, 9 kwietnia 1944 roku, Poznań przeżył drugi podczas trwania wojny nalot bombowy $^{113}$. Nie wiadomo, czy Wera spędziła te święta w Poznaniu. Następna kartka z kolekcji została napisana 9 dni później i nie nawiązywała do tych wydarzeń:

Jest godz. 14 1/4 i alarm. Jesteśmy w biurze. Mam nadzieję, że wszystko dobrze pójdzie. W sobotę wysłałam list polecony [...]. Paczkę nadałam też w sobotę. [...] To jest niesłychane, że Ty tak tyrasz [...]. Tutaj nikt nie wymaga od kobiety powyżej 70 lat takiej harówki. Poza Poznaniem mają być zbudowane mieszkania Führera. Mogłabym dostać 1 pokój z kuchnią dla Ciebie, musisz jak najszybciej się zdecydować. Będą gotowe za 6 tygodni ${ }^{114}$.

${ }^{112}$ Widok Parku Miejskiego ze stawem, sygn. IV-Vas-1944-03-01.

${ }^{113}$ C. Łuczak, Dzień po dniu w okupowanym Poznaniu..., s. 522-524.

${ }^{114}$ Hotel „Ostland” (Hotel „Rzymski”), sygn. IV-Vas-1944-04-18 (Foto Weber). 
Ta propozycja wskazywałaby na wahanie Wery, czy nie zostać na stałe w Poznaniu. W kolekcji brakuje również kartki z reakcją Wery na kolejne bombardowania Poznania 13 i 29 maja 1944 roku. W czerwcu niepokoiły ją następne naloty na Hamburg:

Przekaż mi natychmiast wiadomość, czy jesteś zdrowa i czy nic Ci się nie stało. Mieliście przecież znowu atak. Jestem pełna niepokoju [...]. Tylko parę słów, żebym była spokojna... ${ }^{115}$.

Parę godzin później dostała list od matki:

Byłam tak zdenerwowana, że chciałam dziś rano już telegrafować, ale jak już byłam w drzwiach, zaczął się alarm. $2 \frac{1}{2} 2$ godz. Wczoraj też był alarm ${ }^{116}$.

Mimo coraz trudniejszej sytuacji na obu frontach poczta funkcjonowała w lipcu 1944 roku jeszcze normalnie:

Paczkę wartościową dostałam dzisiaj. Najbardziej ucieszyłam się z kieszonkowego lusterka i 3 spinek do włosów [...], tu nie można ich dostać, a ja zgubiłam już prawie wszystkie. Lustro też potrzebuję, bo moje zbiłam już jakiś czas temu, a z kieszonkowego lusterka zostało mi tylko pół. Z moim urlopem do dziś nic się nie zmieniło i z moją decyzją, żeby wyjechać już w niedzielę też nic. W sobotę 8.7. wysłałam paczkę. Tutaj kilka dni było ładnych i ciepłych. Dzisiaj jest znowu pochmurno. Musi jednak też padać, bo przez nieustanny wiatr wszędzie jest sucho i kurz taki, że ledwo można otworzyć oczy... ${ }^{117}$.

Po powrocie z urlopu w sierpniu Wera V. zastała w Poznaniu inną sytuację:

Tutaj są ogromne zmiany, nie tylko w siedzibie urzędu [...]. Wszystkie urlopy są wstrzymane ${ }^{118}$.

Dzień później napisała już więcej:

Nie przysyłaj mi już paczek, liczę się z przeniesieniem do Hamburga. Przez te 3 tygodnie, kiedy byłam w Hamburgu, wszystko się zmieniło. Szkoda. Nie

${ }^{115}$ Most Teatralny, sygn. IV-Vas-1944-06-21/a.

${ }^{116}$ Schloßberg (Wzgórze Przemysława), sygn. IV-Vas-1944-6-21/b (Foto Weber).

${ }^{117}$ Hotel „Ostland” - zbliżenie, sygn. IV-Vas-1944-07-10.

${ }^{118}$ Biblioteka Raczyńskich, sygn. IV-Vas-1944-08-07. 
mam kiedy napisać listu. Pęka mi głowa. Jak ja zabiorę moje rzeczy? Tutaj panuje teraz rozgardiasz. Możliwe, że tutejszy Urząd Pracy skieruje mnie gdzieś indziej. Panna Sofie wczoraj wyjechała, moja mała gospodyni też [...]. Miejmy nadzieję, że te środki doprowadzą do szybkiego końca wojny i pomogą nam w zwycięstwie ${ }^{119}$.

Ciekawe, czy autorka tych słów w nie wierzyła, czy napisała je z myślą o cenzurze i przypadkowych czytelnikach.

Zmiany były coraz większe:

Nie mam czasu na napisanie listu. Odziały zamiejscowe Stowarzyszenia Rolników w Inowrocławiu, Łodzi i Kaliszu zostały odchudzone, a ich siły oddane do dyspozycji Urzędu Pracy ${ }^{120}$.

Po kilku dniach sytuacja zaogniła się jeszcze bardziej:

Stąd poczta idzie tak długo. Skrzynki pocztowe są przepełnione i prawie nieopróżniane. Tutaj jest piekło. Oddział LBA w Inowrocławiu został zamknięty [...]. Kierownik z Inowrocławia po 3 dniach został cofnięty ze zwolnienia. Mamy go teraz tutaj i interes kręci się dalej. Mój szef był koło Mosiny i nadzorował 15 ludzi. Poza tym kierował stamtąd również nami. Wczoraj dostał powołanie do wojska. Co za szczęście, będziemy mieli go z głowy. Dzisiaj jeszcze się pojawi... ${ }^{121}$.

Poczta z Hamburga dochodziła jeszcze szybko:

Dzisiaj dostałam Twój list z 31.8. Bardzo dziękuję. W ostatnich dniach znowu martwiłam się o Ciebie, ponieważ w międzyczasie Hamburg był 2 x wymieniany w komunikatach Wehrmachtu. Co za szczęście, że wszystko dobrze się skończyło. Ty piszesz jeszcze bardzo, bardzo ładnie bez okularów. Pracujemy od 7.00 rano do $17.30 \mathrm{z}$ półgodzinną przerwą na obiad. W soboty do $14.00 \mathrm{bez}$ obiadu. Od dzisiaj muszę przez 10 dni chodzić na kurs obrony przeciwlotniczej w godz. 20-22 [...]. Będę siadać z tyłu i spać. Tutaj jest już jesień. Dzisiaj już znowu jest ten przeklęty, lodowaty wiatr... ${ }^{122}$.

${ }^{119}$ Residenz-Hotel (róg ulic Gwarnej i Święty Marcin), sygn. IV-Vas-1944-08-08.

${ }^{120}$ Mosina k. Poznania - cukiernia i kawiarnia Adolfa Haupta, sygn. IV-Vas-1944-08-16 (Verlag Hanns Kanngiesser).

${ }^{121}$ Mosina - polski kościól, sygn. IV-Vas-1944-08-23 (Foto Wimar).

${ }^{122}$ Mosina - urząd pocztowy, sygn. IV-Vas-1944-09-01 (Foto Wimar). 
Od początku październiku 1944 roku Wera już nie pracowała w Stowarzyszeniu Rolników:

Odpowiedz mi zaraz, jakie jest ostatecznie Twoje zdanie. Dzisiaj już trzeci dzień nie pracuję. Muszę się szybko zdecydować. Wyjechać czy nie. Poza tym powodzi mi się dobrze. Jest zimno i pada ${ }^{123}$.

Troska o matkę nadal przeważała nad innymi kłopotami:

Dostałam dziś Twój list z 16.10. Chwała Bogu, że żyjesz. Wariowałam już ze strachu o Ciebie. Wysłałam też telegram do NSDAP do szpitala i prosiłam o wiadomość [...]. U nas dotąd nie było alarmu ${ }^{124}$.

Ostatnia widokówka z kolekcji została napisana przez Werę 12 listopada 1944 roku:

Nie mam kiedy wysłać listu poleconego i pieniędzy. Jutro rano obejmuję nową posadę w Wehrmachcie. Zostałam przyjęta 9.11. i mogłam zacząć od zaraz. Przesunęłam to do jutra, bo mam jeszcze dużo prania i pończochy do cerowania. Wszystko mam zniszczone i brudne, bo przez ostatnie 14 dni nic nie mogłam zrobić. Muszę też się nabiegać po moje nowe kartki żywnościowe. Przez to, że nigdy nie było mnie w domu, mój dozorca oddał je naturalnie do Urzędu Gospodarki [...]. Mam nadzieję, że spodoba mi się tutaj. Zaletą jest, że to całkiem blisko od mojego mieszkania i nawet w ciemnościach trafię. Wczoraj wieczorem znowu się przewróciłam... ${ }^{125}$.

Nie wiadomo, jak się potoczyły dalsze losy Wery V. ${ }^{126}$. Wysyłała z Poznania korespondencję do matki przez 3 lata i 9 miesięcy trwania wojny. Jej życie wypełniała przede wszystkim praca zawodowa stenotypistki w Stowarzyszeniu Rolników Kraju Warty w różnych ekspozyturach.

${ }^{123}$ Restauracja E. Prügel, dopisek Martinstr. (ul. Święty Marcin). Na tej kartce podany jest inny adres zamieszkania: Breitestr. 9 (ul. Wielka), sygn. IV-Vas-1944-10-03.

${ }^{124}$ Wnętrze winiarni „Berlin”, sygn. IV-Vas-1944-10-19. Autorka podała dawny adres zamieszkania na ul. Szyperskiej.

${ }^{125}$ Pocztówka z widokiem Generalkommando (Generalna Komendantura), sygn. IV-Vas-1944-11-12 (Foto Weber).

${ }^{126}$ Dzięki uprzejmości mecenasa Pawła Nowakowskiego i konsula RP w Hamburgu Łukasza Koterby udało się ustalić w miejscowym Urzędzie Meldunkowym, że Wera V. (ur. 8 listopada 1901 roku) przeżyła wojnę i zmarła 3 grudnia 1991 roku w Hamburgu, a jej matka Elise zmarła w tym samym mieście w 1945 roku (poświadczone przez Urząd Stanu Cywilnego Hamburg-Wandsbek, Reg. Nr 3358/92). 
Czas wolny poświęcała na prowadzenie prawie codziennej korespondencji z matką (znacznie rzadziej z innymi osobami), zakupy i wysyłanie paczek. Sporadycznie chodziła do kina, na spektakle teatralne czy operowe. Brak tytułów (poza jednym filmem), choćby krótkiego opisu przedstawień sugerowałby, że było to tylko pewne urozmaicenie życia. Czasem otwarcie pisała matce, że w teatrze czy kinie jest cieplej niż w domu. Wera poświęcała dużo uwagi pogodzie. Z jej opisów wynika, że w Poznaniu były wtedy długie zimy, trwały od listopada niemal do końca kwietnia, ale ona skarżyła się na zimno także w maju i sierpniu.

Kiedy w lutym 1941 roku przybyła do Poznania, miejsce to mogło jej się wydawać bardzo atrakcyjne. Pensja bez podatku, wiele artykułów spożywczych reglamentowanych w III Rzeszy mogła tu nabyć bez kartek, spokój w porównaniu z Hamburgiem (w czasie jej pobytu w Poznaniu doszło tylko do trzech poważnych alianckich nalotów bombowych). Z lektury jej widokówek poznajemy trudności z zaopatrzeniem w artykuły spożywcze, odzieżowe i opał w Poznaniu, rosnące wraz z upływem wojny i rozszerzaniem niemieckich działań wojennych. Doskwierały jej zimno, wilgoć i brud w mieszkaniu, walka z pchłami i pluskwami. W 1943 roku pojawiły się w mieście problemy z dostarczaniem wody. Wera V. skarżyła się matce na brak możliwości umycia rąk, na wielogodzinne kolejki do łaźni miejskiej i na zapchane toalety. Brak oświetlenia ulic powodował, że często przewracała się.

Jej życie codzienne bardzo różniło się od losu polskich i żydowskich mieszkańców Poznania. Nie groziła jej utrata życia, obóz koncentracyjny czy aresztowanie za najdrobniejsze przewinienie. Nie była narażona na przymusowe opuszczenie domu czy mieszkania, na dyskryminację, łapanki ani na dotkliwe pobicie na ulicy, np. za niekłanianie się Niemcom czy używanie ojczystego języka. Podczas okupacji niemieckiej prawie każdego dnia dokonywano w Poznaniu egzekucji. Polacy za wykonywanie tej samej pracy otrzymywali niższe pensje niż Niemcy, mieli krótsze urlopy wypoczynkowe, a z czasem zostali ich pozbawieni, dostawali mniejsze przydziały żywności, a o wielu artykułach spożywczych czy odzieżowych mogli tylko marzyć. Ciężka praca i niedożywienie spowodowały wzrost zachorowań na gruźlicę i choroby zakaźne wśród polskich mieszkańców miasta $^{127}$.

Trudno ocenić na podstawie widokówek stosunek autorki do Polaków jako wrogi. W kartce wysłanej w kopercie na początku swego pobytu w Poznaniu bardzo chwaliła polskiego szewca. Pisząc do matki w sierp-

${ }^{127}$ Szerzej zob. C. Łuczak, Dzień po dniu w okupowanym Poznaniu...; idem, Pod niemieckim jarzmem...; E. Serwański, Wielkopolska w cieniu swastyki, Warszawa 1970. 
niu 1942 roku o Polakach, od których musiałaby w nocy odebrać klucze od swojego mieszkania, używała, co prawda, pogardliwego określenia Polacken, ale zdecydowała się na pobyt w poczekalni dworcowej, żeby ich nie budzić. Być może wyraziła się tak z myślą o cenzurze, bo tę widokówkę wysłała bez koperty. Poza tym okazywanie życzliwości Polakom przez Niemców groziło aresztowaniem ${ }^{128}$, a dla Wery mogło skończyć się w najlepszym wypadku odesłaniem do Hamburga.

Autorka wystrzegała się wyrażania opinii na temat Hitlera, narodowego socjalizmu czy toczącej się wojny. O dniu urodzin Führera w 1941 roku pisała dość nieporadnie, zwracając uwagę na pogodę tego dnia. Napomykając, że widziała Josepha Goebbelsa i Roberta Leya w Poznaniu w październiku 1943 roku, uczyniła to bez jakiegokolwiek komentarza, tak jakby chciała tylko donieść matce, że spotkała znane postaci. Na początku pobytu niewiele pisała o swej pracy. W całej korespondencji nie wspomniała nazwiska swego bezpośredniego szefa, choć jego przełożonego, dla którego czasem pracowała, wymieniła z nazwiska i tytułu. Dopiero po powrocie z urlopu wypoczynkowego w sierpniu 1944 roku, kiedy w mieście i w urzędzie panował ogólny chaos, informowała matkę o powolnym rozpadaniu się Stowarzyszenia Rolników w Poznaniu i jego oddziałów zamiejscowych.

Życie codzienne w Poznaniu podczas okupacji zostało ukazane w widokówkach pisanych przez Werę V. bardzo fragmentarycznie. Ona sama często zaznaczała, że więcej napisała lub napisze w liście. Lektura całej korespondencji (listów i widokówek) pozwoliłaby na obszerniejsze odtworzenie jej życia codziennego w Poznaniu.

DOROTA MAZURCZAK

\section{"It's cold round here...". Everyday life of a German office worker in Poznań as described in her post- cards sent home between 1941 and 1944}

Aвstract. One of the largest postcard collection in Poland, housed in Poznań University Library iconographic collection, includes a set of nearly a hundred postcards

${ }^{128} \mathrm{Na}$ przykład w kwietniu 1942 roku aresztowano żołnierza niemieckiego za pomoc Polakowi w wysłaniu paczki żywnościowej (C. Łuczak, Dzień po dniu w okupowanym Poznaniu..., s. 351). 
written by just one person, Wera V., a German clerk working for the German administration of the occupied region in Poznan, in the Agricultural Workers' Association (Landesbauernschaft Wartheland), and sent to the same recipient - her mother in Hamburg in the years 1941-1944. Initially, the new town, Poznan, turned out for the woman to be fairly attractive and a peaceful working place as compared to frequently bombed Hamburg, with such advantages as a tax-free salary, or certain commodities that were rationed in the Reich here obtainable for the German state service office workers without coupons, and just three air raids. However, in the course of the war, the living and working conditions for the Germans began to deteriorate considerably.

Wera's choice of law with which to comply, most likely the fear of the Nazi censorship regulations and, plainly, her self-censorship, made her not reveal her true feelings towards the National Socialism. However, her attitude towards the Poles can hardly be called hostile. Wera V. spent her free time mostly on writing letters, searching for commodities hard to obtain back in the Reich, and sending home parcels with trophies, dirty linen and clothes to be redone. She hardly ever went to the cinema, a cafe, the theatre or the opera - the reason being, more often than not, the cold she found hard to endure. She wrote much about weather, much less about her work. It was only from August 1944, when chaos started to prevail, that she started to write about the changes going on in her office and about shutting down of non-Poznań-based departments. The picture postcards written by Wera V. complemented the letters written to her mother. A closer inspection to Wera's epistolary output could make it possible to reconstruct her everyday life in Poznań more fully.

Key words: everyday life, WWII, Poznań (Posen), picture postcards 